\title{
FAIRNESS AND FLEXIBILITY: UNDERSTANDING CORPORATE BANKRUPTCY'S ARC
}

\author{
Stephen J. Lubben*
}

1.THE EARLY YEARS: DEVELOPING FLEXIBILITY .......................... 139

A. Foreclosure and Execution Sales ................................. 141

B. Receiverships........................................................... 146

2.THE NEW DEAL AND THE MOVE TOWARD FAIRNESS .................. 158

A. Railroad Reorganizations - The 1935 Revamp of Section 77

B. Section 77B and the Chandler Act ............................. 160

3.1978 AND THE RETURN OF FLEXIBILITY....................................... 166

4.MODERN BUSINESS BANKRUPTCY: TOO MUCH FLEX? ................. 172

5.THE WAY FORWARD............................................................. 175

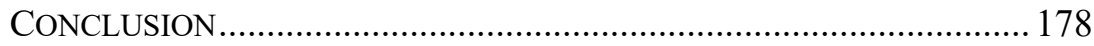

The century and a half story of American corporate reorganization law exhibits a distinctive pattern: a long, slow wave, drifting between flexibility and fairness, and back again. ${ }^{1}$ Flexibility in the corporate bankruptcy process means that it can adapt to changing times and changing corporate structures. Fairness means that the process fully respects the privileges of all stakeholders, without preferences for insiders or repeat players in a process that turns on key questions of who should get paid when there are limited resources.

The two coexist uneasily in corporate bankruptcy: flexibility is enhanced by reducing the number of voices that matter in a corporate restructuring. But reducing voice rather obviously reduces fairness. Flexibility is also a tool that favors large, repeat players, who can learn to use flexibility. Along the way, there is also a temptation to utilize that knowledge in understandably self-interested ways that maximize repeat player recoveries at the expense of the less sophisticated. Indeed, it can be

\footnotetext{
${ }^{*}$ Harvey Washington Wiley Chair in Corporate Governance \& Business Ethics, Seton Hall University School of Law. I am grateful for the comments of Abbye Atkinson, Rich Levin, Virginia Torrie, and the participants in the Brooklyn Law School Advanced Bankruptcy Colloquium.

1. $C f$. Richard Overy, The Morbid Age: Britain Between the Wars 29-49 (2009) (reviewing cyclical theories of history).
} 
said that repeat players will seek out flexibility precisely because it is less fair. On some level, flexibility and fairness will always represent inherent tradeoffs in this context.

That said, and as I develop throughout the paper, there is real risk that fairness considerations are used mostly by other repeat players who have lost in the earlier flexibility competition. Specifically, the small player gets held up as a posterchild for more fairness, when in practice many of the reforms end up being used to the benefit of larger or repeat players.

Restructuring law developed in flexibility, only to have that taken away, first slowly by courts and then abruptly by New Dealers determined to improve corporate reorganization's fairness. Then flexibility returned, somewhat gradually, with the enactment of the 1978 Bankruptcy Code. ${ }^{2}$ After more than four decades under the Code, that flexibility has been expanded to the point where, at least in big chapter 11 cases, it seems that a reorganization can take any form. Whatever key constituencies agree to $e x$ ante can now be packaged in a "Restructuring Support Agreement" and made binding by the court. ${ }^{3}$

Flexibility now reigns supreme. The Code is situated in the extreme; the forces of fairness are primed for a counterattack. Any move to an extreme pole in this regard is inherently incompatible with the opposite; thus, extreme flexibility also means increased deviations from fairness, which makes such a backlash almost inevitable.

$$
\text { *** }
$$

Almost seventy years ago, Walter Blum observed that while corporate finance documents are drafted as if they will be enforced in state court, at a sheriff's sale, the reality has long been that large corporations are never liquidated, but instead reorganized. ${ }^{4}$ One key motivation behind this inclination to reorganize, "is that the assets of a distressed business are not to be disposed of until there has been a reasonable opportunity to determine what disposition will be most advantageous. This principle is so clearly

2. See N.L.R.B. v. Bildisco \& Bildisco, 465 U.S. 513, 525 (1984) (noting "the policies of flexibility and equity built into Chapter 11 of the Bankruptcy Code").

3. See David A. Skeel, The Empty Idea of "Equality of Creditors," 166 U. PA. L. Rev. 699, 701 (2017) ("[I]f we look at current bankruptcy practice, creditor equality seems to be rapidly disappearing. Bankruptcy courts often bless arrangements that give one group of general creditors starkly different treatment than other groups.").

4. See Walter J. Blum, The Law and Language of Corporate Reorganization, 17 U. CHI. L. REV. 565, 566 (1950) (discussing corporate reorganization under the national Bankruptcy Act). 
sound that elaboration is unnecessary."5

American corporate insolvency law developed hand-in-hand with corporations. From the days before the Civil War, to recent times, the everincreasing sophistication of corporate operations and capital structures have called for corresponding changes in the techniques for addressing financial distress. Until Congress could be persuaded to use its powers under the Bankruptcy Clause to address corporations, development of these techniques often involved reshaping existing non-bankruptcy tools to meet new challenges. ${ }^{6}$ This was the story throughout the Nineteenth and early Twentieth Centuries.

Thus, in the very early days before the Civil War and immediately after, large corporations - mostly railroads - were reorganized within the context of a mortgage foreclosure sale. When the foreclosure process was found wanting, receiverships were adapted as a reorganization tool. ${ }^{7}$ In both cases, the reorganization techniques became increasingly flexible, so that by the turn of the twentieth century, large American corporations could restructure their multi-million-dollar capital structures with relative ease. ${ }^{8}$

But soon thereafter, the pushback began. Cries of "collusion" and claims that the court system was being used to reward insiders and cut off small investors soon lead courts to impose increasingly stringent limitations on reorganizations done through equity receiverships. At the same time, these new rules were used by sophisticated holdout creditors to extract more value for their claims. ${ }^{9}$ The receiverships perhaps became "fairer" as a result of the newly imposed rules, but they also were becoming less useful.

Proponents of the receiverships thought they had saved them when the process was codified in the early 1930s as sections 77 and $77 \mathrm{~B}$ of the 1898 federal Bankruptcy Act. The codification did away with the need for an

5. Id.

6. See Sidney Post Simpson, Fifty Years of American Equity, 50 Harv. L. Rev. 171, 190-92 (1936) (explaining how the movement towards large scale industries helped change America's doctrines of equity).

7. See, e.g., Joseph C. Simpson, Comments on the Railroad Reorganization Provisions of the Bankruptcy Act of 1973, 30 Bus. LAw. 1207, 1209 (1975) ("This procedure, developed largely through ingenuity in federal court practice, in effect converted old equity forms originally intended to transform the debtor's property into cash for distribution among creditors into a procedure which achieved the opposite result, namely, preserving the properties intact while adjusting the debts.").

8. See Douglas G. Baird \& Robert K. Rasmussen, Boyd's Legacy and Blackstone's Ghost, 1999 Sup. CT. ReV. 393, 405 (1999).

9. For a general discussion of the holdup problem, see JOHN EVARTS TRACY, CORPORATE ForEClOSURES, RECEIVERShIPS, AND REORGANIZATIONS $§ 299$ (1929). See also Adrian H. Joline, Method and Conduct of the Reorganization of CoRporations 8586 (1910). 
inefficient ancillary receivership system, ${ }^{10}$ and section 77 even did away with the need for receivers, pioneering the "debtor in possession" system that we use today. ${ }^{11}$

Both sections made clear that holdouts could be bound to a reorganization plan supported by a majority. ${ }^{12}$ Moreover, sections 77 and 77B overcame the steady narrowing of the equity receivership architecture by the Supreme Court. ${ }^{13}$

But soon thereafter, railroad receiverships were taken over by the Interstate Commerce Commission in a completely revamped version of section 77, and the Chandler Act replaced section 77B - the general corporate reorganization provision - with chapter $\mathrm{X}^{14}$ Under that new chapter, the reorganization of large companies would be overseen by not only bankruptcy courts, but also the Securities and Exchange Commission, which was specially entrusted to look after the interests of small investors. ${ }^{15}$

Insiders were kept far away from the process, and corporate management replaced with a court-appointed trustee. ${ }^{16}$

10. For a discussion of these costs, see infra note 118 and text.

11. 8 Securities and Exchange Commission, Study and Investigation of the Work, Activities, Personnel and Functions of Protective and Reorganization Committees 104 (1940). See also 11 U.S.C. $\S \S 1101(1), 1107$ (the debtor in possession provisions of the current Code).

12. 8 Securities and Exchange Commission, Study and Investigation of the Work, Activities, Personnel and Functions of Protective and Reorganization COMMITTEES 83-84 (1940).

13. Discussed infra notes 107 to 116 and text.

14. Congress codified the railroad receivership process in 1933 - Act of March 3, 1933, chap. 204, 47 Stat. 1474 (1933) ("section 77") - and the receiverships of other, non-rail corporations in 1934. Act of June 7, 1934, chap. 424, 48 Stat. 211 (1934) ("section 77B"). Leslie Craven \& Warner Fuller, The 1935 Amendments of the Railroad Bankruptcy Law, 49 HARV. L. REV. 1254, 1258-60 (1936). In 1938, the Chandler Act (52 Stat. 840) was adopted. Section 77, relating to railroads, was retained, and Chapter X, Corporate Reorganizations, replaced former section 77B. William O. Douglas, Improvement in Federal Procedure for Corporate Reorganizations, 24 A.B.A. J. 875 (1938). Section 77 essentially put an end to railroad receiverships. Note, Bankruptcy - Railroad Reorganization - Reorganization Under Consent Receivership Held Improper Where Statutory Reorganization Provisions Are Applicable, 57 HARV. L. REV. 1116 (1944) ("Since the enactment of $\S 77$. . the railroads and their creditors have practically abandoned the use of equity receiverships in favor of the statutory system. ...”).

15. Frederick J. R. Heebe, Corporate Reorganization under Chapter X of the Bankruptcy Act, 16 LoY. L. REV. 27, 28 (1969).

16. See Troy A. McKenzie, Bankruptcy and the Future of Aggregate Litigation: The Past As Prologue?, 90 WASh. U.L. Rev. 839, 872 (2013) ("The New Deal reforms essentially closed out the era of large corporate reorganizations... In particular, the Wall Street reorganization lawyers who had been at the center of the practice exited it. The imposition of an independent trustee meant that managers who sought to reorganize would lose control over a firm and, perhaps, their jobs as well.") (footnotes omitted). 
The process was exceedingly fair, but rarely used..$^{17}$ Indeed, whenever possible, debtor-firms attempted to use chapter XI, which had been designed for small businesses. ${ }^{18}$ Somewhat ironically, an era founded on extreme fairness was increasingly utilizing covert flexibility.

With the 1978 Bankruptcy Code, the law we still use today, chapter 11 was revised to allow corporate reorganization of all sorts to proceed under an openly flexible scheme. ${ }^{19}$ At first, the process was dominated by debtors and their management, but by the 1990 s, creditors learned how to play too. ${ }^{20}$ Soon a statute drafted to deal with 1970s businesses was doing a good job reorganizing tech companies and capital structures far more complex than any the drafters could have imagined. ${ }^{21}$

But recently, worries have resurfaced about the fairness of the process. Cases are increasingly filed in jurisdictions far away from the bulk of creditors and employees, and shareholders are increasingly viewed as more of a nuisance than a legitimate stakeholder in the process. Insiders (including controlling creditors) structure deals before cases are filed, and courts have shown a willingness to adopt these deals within the chapter 11 process, despite concerns that the deals might not strictly comply with the Code.

And thus, we see the early signs of backlash.

In its recent opinion in Czyzewski v. Jevic Holding Corporation, ${ }^{22}$ the Supreme Court rejected the idea that a "structured settlement" could be used to end a chapter 11 case on a broadly consensual basis, when doing so would avoid the holdup power granted to a narrow group of objecting creditors. While the Third Circuit had suggested a "rare case" exception that could be

17. See Richard W. Jennings, Mr. Justice Douglas: His Influence on Corporate and Securities Regulation, 73 YALE L.J. 920, 940 (1964) ("Over the years, Chapter X has more and more faded into the background. ...").

18. Walter J. Blum \& Stanley A. Kaplan, The Absolute Priority Doctrine in Corporate Reorganizations, 41 U. CHI. L. Rev. 651, 659 (1974).

19. See In re AG Consultants Grain Div., Inc., 77 B.R. 665, 675 (Bankr. N.D. Ind. 1987) ("The idea behind Chapter 11 of the Code was to combine the speed and flexibility of Chapter XI with some of the protection and remedial tools of Chapter X."). See also Michelle M. Harner, The Search for an Unbiased Fiduciary in Corporate Reorganizations, 86 NOTRE Dame L. Rev. 469, 484 (2011); William C. Whitford, What's Right About Chapter 11, 72 WASH. U. L.Q. 1379, 1399 (1994).

20. Although academics perhaps overstated the lessons that could be learned from the specific market conditions present in the late 1990s and early 2000s. See Stephanie Ben-Ishai \& Stephen J. Lubben, Involuntary Creditors and Corporate Bankruptcy, 45 U. BRIT. Columbia L. Rev. 253, 265-66 (2012).

21. See generally Hon. Leif M. Clark, Chapter 11-Does One Size Fit All?, 4 Am. BAnKR. INST. L. REV. 167, 183 (1996) (noting that "the extraordinary flexibility of chapter 11 has proven itself in handling a wide panoply of business enterprises - and business problems").

22. See Czyzewski v. Jevic Holding Corp., 580 U.S. 1, 3 (2017) (analyzing the legality of a distribution scheme employed by a company filing for Chapter 11 bankruptcy). 
applied sparingly for sufficient reasons, the Supreme Court baulked, noting that "it is difficult to give precise content to the concept 'sufficient reasons.' That fact threatens to turn a 'rare case' exception into a more general rule." Instead, the Court held that the absolute priority rule "has long been considered fundamental to the Bankruptcy Code's operation," and that the "priority system constitutes a basic underpinning of business bankruptcy law." In short, follow the rules.

Other cases have rejected the "gifting" of senior creditor recoveries to junior players ${ }^{23}$ or the use of the old "doctrine of necessity" to pay important trade creditors in full during a chapter 11 case. ${ }^{24}$ The flexibility of modern chapter 11 risks being slowly rolled back. ${ }^{25}$

In many respects, chapter 11 today is much like corporate reorganization in the early 1930s, when after a brief "wobble" in the 1920s, due to some unhelpful Supreme Court decisions, it looked like the basic reorganization structure had stabilized around sections 77 and 77B. The modern widespread use of aggressive restructuring support agreements that set forth deals with only an incidental connection to the actual structure of the 1978 Bankruptcy Code looks much like the very same smugness that pervaded section 77 and 77B cases right up until the New Dealers announced "enough."."

Are we fated to travel back to the other extreme, "reforming" chapter 11 so much that it ceases to be useful?

The key insight of this paper is that neither extreme fairness nor extreme flexibility are stable states for our system of corporate reorganization, because moves to extreme fairness tend to render reorganization systems unusable, and the need for a functional reorganization system will inherently force a move back from fairness and toward flexibility. Moreover, claims of "fairness" are too easily coopted by repeat players seeking an edge on their rivals. But extreme flexibility is also unstable, in that it invites the kind of

23. See generally In re DBSD N. Am., Inc., 634 F.3d 79, 98 (2d Cir. 2011) (ruling on the legality of DBSD North America's restructuring plan).

24. See In re Kmart Corp., 359 F.3d 866, 871 (7th Cir. 2004) (holding that a bankruptcy court may issue any order necessary to ensure that the parties comply with all provisions of the Bankruptcy Code).

25. See In re Lehman Bros. Holdings Inc., 508 B.R. 283, 294 (S.D.N.Y. 2014) ("Although flexibility is necessary ... the federal scheme cannot remain comprehensive if interested parties and bankruptcy courts in each case are free to tweak the law to fit their preferences. ...") (citation omitted).

26. See generally Edward J. Janger \& Adam J. Levitin, Badges of Opportunism: Principles for Policing Restructuring Support Agreements, 13 BROOK. J. CORP. Fin. \& COM. L. 169 (2018) (analyzing the use of restructuring support agreements in corporate control transactions within the bankruptcy context). 
backlash this introduction has outlined.

Deeper understanding is needed before true (and lasting) reform can be achieved.

$$
* * *
$$

This paper begins by tracing the history of the cycle of American corporate bankruptcy law between fairness and flexibility. ${ }^{27}$ Part 1 recounts the early journey from mortgage foreclosures to equity receiverships, a story that largely turns on the growth of railroads as multi-state businesses. Here, we see the growing flexibility of corporate reorganization procedures, as they use old forms in new and creative ways.

Part 2 picks up the story in the New Deal and carries it up to the Jimmy Carter years. Here we see the move back toward fairness, but with a corporate reorganization process that was of declining utility, particularly for larger businesses. In many respects it is remarkable that the nation persisted as long as it did - about forty years - with such a deficient reorganization system.

Part 3 then looks at the adoption of the current Bankruptcy Code in 1978. The story becomes a move once again toward flexibility, as the several reorganization provisions of the old Bankruptcy Act were folded into a single reorganization chapter: today's chapter $11 .^{28}$ Prepacks, 363 sales, first day motions, and then restructuring support agreements have all molded chapter 11 into a tool that could support nearly any form of corporate reorganization.

Part 4 then examines the growing move to reign in the flexibility of chapter 11. The Supreme Court's opinion in Jevic, the backlash against the 2009 automotive chapter 11 cases, the widespread disdain for permitting bankruptcy judges to exercise discretion, ${ }^{29}$ and the preference for fixed rules, all point toward a new move toward fairness.

27. Cf. Mark J. Roe, Three Ages of Bankruptcy, 7 HARV. Bus. L. REv. 187 (2017) (telling a substantially different story of bankruptcy law's cycles that relies on underlying market conditions as a "major explanation" for the changes in bankruptcy law).

28. Frederick Tung, Confirmation and Claims Trading, 90 Nw. U. L. Rev. 1684, 17121713 (1996).

29. Reflected in the business context in things like section 560, which prohibits any sort of injunction in connection with a swap (derivative), even when the alleged "swap" might be little more than an ordinary supply contract. See also 11 U.S.C. § 101(53B) (defining "swap agreement" to include most every sort of derivative, including "any agreement or transaction that is similar to any other agreement or transaction referred to in this paragraph and that ... is a . . swap.”). See Stephen J. Lubben, Subsidizing Liquidity or Subsidizing Markets? Safe Harbors, Derivatives, and Finance, 91 AM. BANKR. L.J. 463, 471-72 (2017) (providing an overview of the derivative safe harbors in the Code, including section 560). 
In Part 5, I then argue caution in making this move, not so much because I believe that concerns expressed about current chapter 11 practice are misguided, so much as I fear the proffered remedies are worse than the underlying problem. In short, I fear that in remedying the problems with chapter 11 in its current guise, we are enabling a new era where the holdout creditor will reign supreme. Moreover, many attempts to set fixed, inflexible rules into the corporate reorganization process simply reflect one group's triumph over another. And in a fight among large, sophisticated investors hedge fund $\mathrm{A}$ vs. distressed debt fund $\mathrm{B}-\mathrm{I}$ see no reason to take sides.

Thus, I conclude by arguing that changes to help the legitimate interests of small players getting crushed in the current system are worthwhile, but "reforms" that ultimately help distressed debt investors or other asset managers extract greater returns from bankrupt corporations are misguided at best. Moreover, as shown by an analysis of the prior reign of tremendous fairness - from about 1938 to 1978 - such a system is inherently unstable because the corporate reorganization system becomes unworkable. Rigidity increases the pressure for change and the likelihood of stealth evasion. The best solution then is to scale back the extremes of the present ultra-flexible chapter system, without going so far as to thwart its very utility.

Indeed, only by appreciating the inherent contradiction between political discourse that emphasizes the small player, on the one hand, and the actual practice of so many restructuring law reforms (which tend to benefit big players) will we understand why attempts to bring fairness to corporate bankruptcy have so often proven unstable.

\section{THE EARLY YEARS: DEVELOPING FLEXIBILITY}

Until the Bankruptcy Act was signed into law by President McKinley on July 1, 1898, federal bankruptcy law consisted of three laws, each of limited duration. ${ }^{30}$ Moreover, even the 1898 Act excluded railroads, which had long been seen as vital public utilities that could not be permitted to liquidate in bankruptcy or otherwise. ${ }^{31}$ As one latter commentator noted,

30. This history is discussed in finer detail in Stephen J. Lubben, A New Understanding of the Bankruptcy Clause, 64 CASE W. Res. L. Rev. 319 (2013). See also 3 JosePh Story, Commentaries ON THE Constitution of the United States $\S 1108$ (1833) ("It is well known, that the power has lain dormant, except for a short period, ever since the constitution was adopted; and the excellent system, then put into operation, was repealed, before it had any fair trial, upon grounds generally believed to be wholly beside its merits, and from causes more easily understood, than deliberately vindicated.").

31. Barton v. Barbour, 104 U.S. 126, 135 (1881). My focus is on large corporations generally, but until the late 19th century, we can largely assume that all large corporations were railroads. 
railroads developed the earliest forms of corporate reorganization, because

To an even greater extent than in the case of private corporations, the solution to the financial difficulties of a railroad lies in reorganization, for regardless of what may be the best interest of its creditors or of its owners, a definite public policy demands that the operation of the business be continued to avert a failure of railroad service and that dismantling of the road be avoided. It is clear that liquidation in bankruptcy cannot satisfy this demand. ${ }^{32}$

As a result of their exclusion from the Bankruptcy Act, all railroad reorganizations took place outside the federal bankruptcy system, until such reorganizations were codified during the New Deal. ${ }^{33}$ In the early days particularly the $1850 \mathrm{~s}$ and $60 \mathrm{~s}$ - foreclosure sales were commonly used to address over-indebted railroads. The railroads of this period tended to be smaller, single-state operations. ${ }^{34}$

But as railroads grew in scope, different mortgages typically covered different assets. The original line would be covered by one mortgage, the new extension to Boston or Los Angeles funded by a new issue of secured bonds, and the branch line to Miami by yet another. ${ }^{35}$

As one learned commentator summarized:

The chief difference between railroad mortgages and other mortgages is based upon the fact that other mortgages merely hypothecate certain specific articles, which remain constant in kind and quality, while a railroad mortgage is the pledge of a venture, the assignment of " $a$ going concern"-a changing and growing security. ${ }^{36}$

A single foreclosure would not keep the railroad together as a going concern, and the use of equity receiverships eventually took the place of earlier foreclosure techniques. ${ }^{37}$

32. 1 John Gerdes, Corporate Reorganizations $\S 10$ ( $3^{\text {rd }}$ ed. 1936).

33. Corporations in general initially were excluded from filing voluntary petitions under the 1898 Act, and "[b]y 1910, when amendments finally broadened the scope of bankruptcy, the pattern of equity reorganization had already been definitely fixed." 8 SEC. AND EXCH. COMM'N, RePort ON THE STUDY AND INVESTigation OF THE WORK, ACTIVITIES, PERSONNEL and Functions of Protective AND Reorganization Committees 62 (1940).

34. See e.g., Campbell, The Reorganization of the American Railroad System, 18931900 at $11(1928)$.

35. See D.H. Chamberlain, New-Fashioned Receiverships, 10 Harv. L. Rev. 139, 140 (1896) (explaining that railroads were typically covered by mortgage bonds and the holders of those mortgages were "numerous and widely scattered").

36. Henry H. Ingersoll, Rights and Remedies of General Creditors of Mortgaged Railways, 19 YALE L.J. 622, 624 (1910) (emphasis in original).

37. $C f$. Harry G. Guthmann \& Herbert E. Dougall, Corp. Fin. Pol'y 329 ( $4^{\text {th }}$ ed. 


\section{A. Foreclosure and Execution Sales}

In the early Nineteenth Century, it was well settled that, absent legislative authorization, a corporation could not mortgage its "franchise" or special rights given by the legislature. ${ }^{38}$ While the concepts of the charter, franchise or privileges were sometimes run together, the first two were distinguishable from the latter:

What is called the franchise of forming a corporation is really but an exemption from a general rule of the common law prohibiting the formation of corporations. In former times, this exemption was granted only in exceptional cases, by a special charter in each instance. It was, therefore, looked upon as something valuable, as a gift of a special privilege to the grantees of the charter, and was called a "franchise." "39

As the New Hampshire Supreme Court said in 1856, a "corporation, being itself a franchise, consists and is made up of its rights and franchises." Or as the Texas Supreme Court explained shortly thereafter, "the charter is a grant of franchises by the state. ${ }^{41}$

Thus, the power to use the franchise as collateral had to be expressly given by the state, either in the charter itself or in a separate statute. For example, in Texas state law provided that

no company shall have the power to make any trust deed or mortgage on the franchise or property of the company, unless the

1962) ("Because separate properties are separately mortgaged, the status of different bond issues is often obscure until reorganization takes place. Foreclosure and acquisition of the mortgaged property seldom occur because the separate units usually cannot be operated to the greatest advantage except as parts of a unified going concern. The right of foreclosure therefore serves mainly to give the holders of a specific lien bargaining power in any reorganization in proportion to the profitableness and importance of the property pledged to them.").

38. Pullan v. Cincinnati \& Chi. Air-Line R.R. Co., 20 F. Cas. 32, 35 (C.C.D. Ind. 1865) (No. 11,461); Coe v. Columbus, Piqua \& Ind. R.R. Co., 10 Ohio St. 372, 394 (1859).

39. Victor Morawetz, A Treatise on the Law of Private Corporations 884 (2d ed. 1886). See also R. Mason Lisle, Foreclosure of Railway Mortgages, 20 AM. L. Rev. 867, 868 (1886) ("Incorporation is the creation of an artificial person, which can only exist by the grant of the sovereign power; hence when the latter creates a corporation, it grants a liberty or a franchise for it to exist.").

40. Pierce v. Emery, 32 N.H. 484, 507 (1856).

41. State v. S. Pac. R.R. Co., 24 Tex. 80, 122 (1859) ("The correct view of the subject is, that the charter is a grant of franchises by the state, and the rights granted to the company, are limited by the charter. They have a right to be a corporate body-that is, a franchise; they have a right to construct a public railroad, and charge for its use (incidental powers are conferred to accomplish these objects); these constitute a franchise. These franchises are the private property of the company ...."). 
power is expressly given by the by-laws of the company. ${ }^{42}$

Here the State grants the power but requires a further step: the adoption of a relevant bylaw.

But once the power to mortgage was established, a natural question arose: What remedies did the creditors have under such a mortgage? In particular, as railroads in this era were created by legislative act, ${ }^{43}$ did the purchasers of the railroad at a foreclosure sale need to go back to the legislature to get a new corporate charter, to hold the assets obtained at the sale?

The courts soon developed a rule that the power to foreclose on the franchise included the power to operate under a charter, a holding that was soon confirmed by statutes in several jurisdictions. ${ }^{44}$ An 1863 New York treatise summarized the law at that time as follows:

The sale by virtue of a decree granted on a mortgage foreclosure of the franchises and corporate property vests in the purchaser the right to use and enjoy both, as the same were used and enjoyed when the mortgage was given; without any liability for debts or obligations created subsequent to the mortgage. This is a legitimate inference from the power to mortgage the franchise and corporate property. The corporation still subsists notwithstanding the foreclosure, and its business can be carried on under the original charter, by the purchasers or their assigns. ${ }^{45}$

This is also reflected in the statutes enacted in this era. For example, the Texas act of December 19, 1857, section 5 (article 4912) provided:

The road-bed, track, franchise, and chartered rights and privileges of any railroad company in this State shall be subject to the payment of the debts and legal liabilities of said company, and may be sold in satisfaction of the same ... the purchaser or purchasers

42. Act of December 1857, sec. 4, reprinted in George W. Paschal, A Digest of the LAWS OF TEXAS 820 (1870).

43. Joseph A. Ranney, A Fool's Errand? Legal Legacies of Reconstruction in Two Southern States, 9 TeX. WesLEYAN L. REV. 1, 39 (2002) ("Texas placed some limits on private incorporation laws before the Civil War; the 1845 constitution allowed the legislature to create private corporations only by a two-thirds vote of each chamber.").

44. Simeon E. Baldwin, American Railroad Law 464 (1904) ("Power given to a railroad company to mortgage its railroad implies power to mortgage the franchise to operate it, for otherwise the property, in case of foreclosure, would fail to serve its proper purposes and the public interest might be prejudiced."). See also Rights Acquired by Purchasers of Public Utilities at A Judicial Sale, 50 HARv. L. Rev. 1303, 1307 (1937) (citing legislation that "would grant to the purchaser those rights of the old company covered by their terms" and the ability to "operate the business as a corporation.").

45. John Willard, Treatise On EQuity JuRiSPRUdENCE 744 (1863). 
at such sale, and their associates, shall be entitled to have and exercise all the powers, privileges, and franchises granted to said company by its charter, or by virtue of the general laws of this State; and the said purchaser or purchasers and their associates shall be deemed and taken to be the true owners of said charter and corporators under the same, and vested with all the powers, rights, privileges, and benefits thereof, in the same manner and to the same extent as if they were the original corporators of said company. $^{46}$

And under section 9 (article 4916) of the same Texas act, "the directors or managers of the sold-out company at the time of the sale, by whatever name they may be known at law, shall be the trustees of the creditors and stockholders of the sold-out company, and shall have full powers to settle the affairs of the sold-out company." 47

The net effect of such a foreclosure sale was to create a new company - operating the very same railroad, yet entirely free from claims and equity interests associated with the old railroad. ${ }^{48}$ The old company - now stripped of its railroad assets - continued as a trust to pay off its remaining creditors and, if possible, the shareholders. ${ }^{49}$ As one commentator explained, "the franchises pass with the mortgaged property as they were meant to, all that is vital is thus transferred, and there is neither injustice nor incongruity in holding that the legislature may treat the substance instead of the shadow as representing the corporate body." 50

And the law was "well settled that stockholders are not entitled to any share of the capital stock nor to any dividend of the profits until all the debts of the corporation are paid." ${ }^{, 51}$ That is, the shareholders of the old railroad had no entitlement in the new railroad, and they also had no entitlements in

46. PASCHAL, supra note 42 , at 820 (emphasis added).

47. PASCHAL, supra note 42, at 820-21.

48. Morgan City. v. Thomas, 76 Ill. 120, 147 (1875); Commonwealth v. Cent. Passenger Ry., 52 Pa. 506, 512 (1866); Vilas v. Milwaukee \& Prairie du Chein Ry. Co., 17 Wis. 497, 502-03 (1863). See also Hous. \& T.C.R.R. Co. v. Shirley, 54 Tex. 125, 137-38 (1880) ("But clearly the purchaser of property at a sale under an execution or deed of trust assumes no personal liability for the debts of the former owner; and if by such a purchase the chartered rights and corporate existence and privileges of a corporation pass under the control of the purchaser, it still does not follow that its liabilities also attach to him.").

49. Witherspoon \& Lane v. Tex. Pac. R.R. Co., 48 Tex. 309, 319 (1877).

50. Lisle, supra note 39 , at 873 . The author goes on to state, "[i]n the absence of legislation, there might be some awkwardness in giving a precise legal definition to the new arrangement, but there could be none concerning its substantial rights. There could be no diminution of the privileges mortgaged without impairing the value of the mortgage as a security."

51. R.R. Co. v. Howard, 74 U.S. 392, 409-10 (1868). 
the estate of the old railroad until all creditors were paid in full. ${ }^{52}$

As one knowledgeable author, writing at the turn of the century, wryly summarized:

... the procedure was simplicity itself. The trustee of the mortgage went into court, or resorted to the ordinary summary power of sale, and foreclosed the equity of redemption of the mortgagor. The stock, to use an expression more forcible and familiar than elegant, was "wiped out." That was the end of it. The unsecured creditor retired to his place of business, charged the debt to profit and loss account, and endeavored to make up his loss by over-charging the successor company. The stockholder went into the market to find some more bargains, hoping by a lucky stroke to "average." 53

Likewise, in 1880, the Texas Supreme Court explained that the "plain intent of the [1857] statute is to transfer the roadbed, track, franchise and chartered rights entire to the purchaser and associates, upon their adopting the form of organization prescribed in the charter and complying with its other requirements; and to remit creditors unsecured by lien to their remedy against such assets as pass to the trustees of the sold-out company. ${ }^{54}$

In short, upon sale, a new railroad was created in the buyer, and the rights of the creditors and shareholders in the old company remained with the old company. ${ }^{55}$ The "franchises would not be forfeited to the State, but transferred to the purchasers; and the State could not revive the old corporation by a regrant of the franchises, which had become vested in the

52. Leonard A. Jones, A Treatise on the Law of Railroad And Other Corporate SECURITIES INCLUDING MUNICIPAL AID $\$ 640$ (1879).

53. Adrian H. Joline, Railway Reorganizations, 8 AM. LAw. 507, 508 (1900). Joline was a well-known reorganization lawyer of his day, who also often served as a receiver. E.g., United States v. Whitridge, 231 U.S. 144, 146 (1913) ("In the same years (1909 and 1910) certain other lines of street railway in the city of New York, which may be described as the Metropolitan system, were in the possession of the respondents Joline and Robinson as receivers ....").

54. Houston \& T.C.R.R. Co. v. Shirley, 54 Tex. 125, 139 (1880).

55. Id. at 139 ("Under this statute it is believed that a number of railroads in this state have been sold out and purchased by individuals, who have proceeded to organize and manage the corporation under the original charter. Not only the road-bed and other mortgaged property, but the franchise to operate a road and the very corporate existence of the sold-out railroad passes to the new organization by virtue of the statute. Ordinarily such purchaser and associates need no further legislation." (citation omitted)); see also Thayer v. Wathem, 17 Tex. Civ. App. 382, 392, 44 S.W. 906, 910 (1897) ("The effect of these decisions, as we understand them, is that when a railway and franchises are sold the corporation is not dissolved thereby, but 'the corporation continues, and the purchasers become in effect new stockholders.'”). 
purchasers. ${ }^{" 56}$ Thus, one commentator concluded that

both upon principle and by the decisions of the courts of the country, that under a legislative authority to mortgage "all the rights, privileges and franchises" of a railroad company with an unalterable charter, the company executing such a mortgage will, at a foreclosure sale, pass to the purchasers the corporate existence. $^{57}$

Frequently this was done as part of an overall plan of reorganization. As the U.S. Supreme Court explained in 1883,

it rarely happens in the United States that foreclosures of railway mortgages are anything else than the machinery by which arrangements between the creditors and other parties in interest are carried into effect, and a reorganization of the affairs of the corporation under a new name brought about. It is in entire harmony with the spirit of bankrupt laws, the binding force of which, upon those who are subject to the jurisdiction, is recognized by all civilized nations. ${ }^{58}$

Thus, a mechanism with a long history, mortgage foreclosure, was readapted to become a corporate reorganization tool. Mortgage foreclosure ultimately proved inadequate to reorganization of a large, multi-state business. ${ }^{59}$ But in these early cases, we see the foundation of the more sophisticated practice that developed in the late Nineteenth Century: sale of the operating railroad to a new corporation that would maintain those operations. ${ }^{60}$

56. Pierce v. Emery, 32 N.H. 484, 512-13 (1856).

57. Lisle, supra note 39 , at 888 .

58. Canada S. Ry. Co. v. Gebhard, 109 U.S. 527, 539 (1883).

59. See Hand v. Savannah \& Charleston R.R. Co., 12 S.C. 314, 329 (1879) ("It is to be presumed that the necessary proceedings will be instituted in the court of the State of Georgia for the adjudication of the rights of parties in the portion of the road lying in that state; and that by the comity of the respective courts, or by the agreement of parties, a time of sale, assented to in each jurisdiction, will be eventually fixed upon."). Accord Midland Valley Ry. Co. v. Moran Nut \& Bolt Mfg. Co., 97 S.W. 679, 680 (Ark. 1906) ("The judgment in this case was correct in form in fixing a lien on all the property of appellant railroad in the state of Arkansas, but it was erroneous in allowing that lien to be made up of material furnished and used in the construction of appellant's road in the Indian Territory."). New York had (indeed, still has) a helpful statute to cover this problem, but many other states did not. LEONARD A.

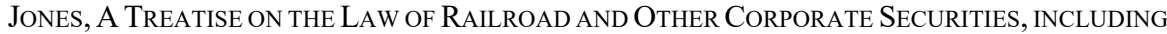
Municipal Aid Bonds $\$ 659$ (1879).

60. See De Forest Billyou, Priority Rights of Security Holders in Bankruptcy Reorganization: New Directions, 67 HARv. L. Rev. 553, 557 (1954) ("Corporate reorganization through an equity receivership developed, not as a substitute for the liquidation of an insolvent corporation, but rather from the limitations of a simple mortgage 


\section{B. Receiverships}

While receiverships in their traditional form have a very long history, ${ }^{61}$ during the nineteenth century they were transformed into a unique and flexible tool for reorganizing insolvent railroads. ${ }^{62}$ The precise point at which receiverships began to be used as a reorganization device is unclear, ${ }^{63}$ but by the 1880s receiverships had clearly surpassed foreclosures as the favored means of addressing financial distress:

The new and changed condition of things which is presented by the insolvency of such a corporation as a railroad company has rendered necessary the exercise of large and modified forms of control over its property by the courts charged with the settlement of its affairs and the disposition of its assets. Two very different courses of proceeding are presented for adoption. One is the old method, usually applied to banking, insurance, and manufacturing companies, of shutting down and stopping by injunction all operations and proceedings, taking possession of the property in the condition it is found at the instant of stoppage, and selling it for what it will bring at auction. The other is to give the receiver power to continue the ordinary operations of the corporation, to run trains of cars, to keep the tracks, bridges, and other property in repair, so as to save them from destruction, and as soon as the interest of all parties having any title to or claim upon the corpus of the estate will allow, to dispose of it to the best advantage for all, having due regard to the rights of those who have priority of

foreclosure.").

61. See Henry G. Tardy, A Treatise on the Law and Procedure of Receivers $\S 1$ (2d ed. 1920) ("It is a power which the Court of Chancery of England frequently exercised long before the establishment of the United States ....”). See also Fred F. Lawrence, A TREatise ON THE SubSTANTIVE LaW OF Equity JuRISPRUDENCE $§ 1108$ (1929) ("The power of equity courts to appoint receivers is ancient, it being one of the oldest of chancery remedies. It was not an incident to the authority of common law tribunals. It was exercised as early as the time of Edward VI ....") (footnote omitted).

62. Gross v. Missouri \& A. Ry. Co., 74 F. Supp. 242, 244 (W.D. Ark. 1947) ("Instructions were issued to the receivers directing them (1) to request the Interstate Commerce Commission to refrain for a period of 90 days from rendering a decision on defendant's action for a certificate of convenience and necessity to abandon the railroad, (2) to receive and consider plans for resumption of operation, and (3) to consider any offer to purchase or lease the whole or any part of said railroad.").

63. Charles Warren argued that federal courts were reluctant to appoint receivers before 1880. Charles Warren, Federal and State Court Interference, 43 HARV. L. REV. 345, 364 (1930). In Vermont, one such receivership reportedly was commenced "prior to 1861" and remained pending in the early 1880s. M.M. Cohn, Railroad Receiverships - Questions of Practice Concerning Them, 19 Am. L. Rev. 400, 410 (1885). 
claim. $^{64}$

Receiverships in the early days were sometimes commenced in response to suits by unpaid secured bondholders. In later years, they were most often instituted in response to a suit by an unsecured creditor (a "creditor's bill"), coupled with the debtor's admission that the debt was due and the railroad was unable to pay. ${ }^{65}$ This was the "friendly" or consent receivership that New Dealers would bemoan as "collusive" and the source of much insider dealing. ${ }^{66}$

As one commentator noted:

From the standpoint of the corporation involved, such a method of

64. Barton v. Barbour, 104 U.S. 126, 134-35 (1881).

65. See, e.g., Louisville Trust Co. v. Louisville, N.A. \& C. Ry. Co., 174 U.S. 674, 67678, 687-88 (1899) (detailing how a court appointed a receiver following a creditor's complaint); Brassey v. N.Y. \& N.E.R. Co., 19 F. 663, 669-70 (C.C.D. Conn. 1884)(“'I am of the opinion that when a railroad corporation, with its well-known obligations to the public, has become entirely insolvent, and unable to pay its secured debts, unable to pay its floating debt, and unable to pay the sums due its connecting lines, unable to borrow money, and in peril of the breaking up and destruction of its business, and confesses this inability, although no default has as yet taken place upon the securities owned by the orator, but a default is imminent and manifest, a case has arisen where, upon a bill for an injunction against attacks upon the mortgaged property, and a receivership to protect the property of the corporation against peril, a temporary receiver may properly and wisely be appointed."). See James Byrne, The Foreclosure of Railroad Mortgages in the United States Courts, in Some LegaL Phases Of Corporate Financing, Reorganization And Regulation 77, $79-81$ (1917) (explaining that unsecured creditors were used to reach all property and assets controlled by the railroad, and not just the property subject to any specific mortgage).

66. Modern scholars, beginning with Albro Martin, have lavished much attention on the Wabash case, where Jay Gould somehow convinced a federal court to approve the railroad's own petition for a receivership. Wabash, St. L. \& P. Ry. Co. v. Cent. Tr. Co., 22 F. 272, 273 (C.C.E.D. Mo. 1884) ("True, the proceeding is peculiar in this aspect: that the application was made by the corporation itself, instead of being made by the mortgagee on default of payment of interest."); Albro Martin, Railroads and the Equity Receivership: An Essay on Institutional Change, 34 J. Econ. Hist. 685, 708 (1974); see also Lubben, Railroad Receiverships and Modern Bankruptcy Theory, infra note 119, n. 106 ("The Wabash receivership is often said to be the first case to allow the debtor to initiate its own receivership, thereby moving railroad reorganization closer to modern Chapter 11 practice.”). But the consent receivership was far more important, because it not only launched the reorganization process, but it provided federal courts with diversity jurisdiction, since the friendly petitioning creditor was always from outside the home state of the railroad. Warner Fuller, The Background and Techniques of Equity and Bankruptcy Railroad Reorganizations-A Survey, 7 LAW \& CONTEMP. Probs. 377, 378-80 (1940). Accord 8 SeC. And Exch. Comm'N, Study and Investigation of the Work, Activities, Personnel and Functions of Protective and Reorganization Committees 24 (1940) ("The procedure failed to crystallize along these lines [i.e., the Wabash approach]; instead, there was increasing resort to another, and less novel, form of legal action. This was the general creditor's bill, out of which the standard procedure was even then being fashioned in other cases."). 
securing a receivership is to be commended for several reasons. It is simple, as almost any large corporation can secure the cooperation of a non-resident creditor with a claim of $\$ 3,000$ or more. It is expeditious, for the bill praying for a receiver and the answer consenting can be filed within a few minutes of each other. It allows the corporation in financial difficulties to have the protection of the United States court. ${ }^{67}$

Normally an unsecured creditor cannot obtain a receiver until the creditor has received a final judgment on its debt, a receiver being more in the nature of a remedy than an end in itself. But, if the defendant railroad were to file an answer admitting the validity of the debt, and its inability to quickly pay the same, the courts felt comfortable moving quickly to the remedy stage. ${ }^{68}$

Early receiverships were first conducted in state courts. Later, receiverships moved to federal court, as the federal judges had somewhat broader jurisdiction, and developed clear procedures for recognition of the receivership in all districts where the railroad might have property. ${ }^{69}$ Moreover, a nineteenth century federal circuit judge could enter an order appointing the receiver in all districts within the circuit, something no state court judge could do. ${ }^{70}$ Likewise, after 1911 (and the abolition of the old circuit courts), federal district courts had the power to appoint a single receiver for all fixed property within the circuit. ${ }^{71}$

In state courts, or when reorganizing larger businesses in federal court, ancillary receivers would be appointed in all jurisdictions outside the circuit

67. Thomas A. Thacher, Some Tendencies of Modern Receiverships, 4 CALIF. L. REV. 32, 34 (1916).

68. For a good overview of the procedure, see 3 RALPH EWING CLARK, A TREATISE ON THE LAW AND PRACTICE OF RECEIVERS $§ 855$ (3d ed. 1959), at 1339. Eventually this process of "consent receivers" was adopted by the state courts too. See New England Theatres, Inc. v. Olympic Theatres, Inc., 287 Mass. 485 (1934) ("The question, whether such an appointment should be made, rests in sound judicial discretion, to be exercised only with circumspection and only in cases where otherwise there would be wasting and loss of property which ought to be made available for payment of the debts of the corporation and which cannot be conserved in any other way so satisfactorily as by the appointment of a receiver.").

69. See Warren, supra note 63, at 364-65 ("[I]t became customary for a corporation to apply in the federal courts itself, or (if it could not sue) through some "friendly" creditor with requisite diverse citizenship; and frequently races arose between an adverse creditor seeking a receivership in a state court, and a "friendly" creditor petitioning in a federal court.").

70. Kingsport Press v. Brief English Sys., 54 F.2d 497 (2d Cir. 1931) contains a good description of the process, including the debtor's communication with its petitioning creditors and the ultimate appointment of the debtor's president as receiver.

71. Judicial Code of $1911 \S 56$, Pub.L. 61-475, 36 Stat. 1087. The circuit courts had lost their appellate jurisdiction back in the 1890 s but were not phased out as trial courts until the passage of this law, nearly 20 years later. 
or state where the main case was pending. ${ }^{72}$ In some instances, these would be the same receivers as in the main proceeding. But in many cases, local receivers, with local counsel, would be appointed. In the main cases, the receiver was frequently an officer of the debtor, providing a kind of precursor to the "debtor in possession" concept. ${ }^{73}$

In all cases, the goal was to place the railroad's assets under court control and out of the reach of individual creditors. ${ }^{74}$ Foreclosure and other collection activity was halted while the creditors negotiated a reorganized capital structure for the railroad. Creditors, and sometimes even shareholders, were represented in this process by committees. ${ }^{75}$

While the committees negotiated, the receivers would often spruce up the railroad. ${ }^{76}$ These improvements were funded by "receivers' certificates," essentially a form of priority debt instrument issued by the receiver and paid off by the receivership estate. ${ }^{77}$

Once a plan was agreed upon, foreclosure suits resumed. The railroad was purchased in exchange for the various defaulted bonds under a joint

72. 8 Sec. and Exch. Comm'n, Study and Investigation of the Work, Activities, Personnel and Functions of Protective and Reorganization Committees 30-33 (1940) ("In the case of other than railroad corporations, this necessity created problems of administration which appreciably retarded the speed of reorganization. In every type of case it involved the additional preparation of many sets of legal papers, the employment of ancillary receivers and of counsel for each of them, and, in general, a needless duplication of much effort and expense.”).

73. Cf. 11 U.S.C. $§ 1107$.

74. Taylor v. the Philadelphia \& Reading R.R. Co., 7 F. 381, 385 (C.C.E.D. Pa. 1881) ("The custody of the property of this railroad devolves upon the receivers appointed by the court. They are custodians of it for the benefit of the creditors. As the object of the whole proceeding is the preservation of the property for the benefit of the creditors. ..."). See also In re Higgins, 27 F. 443, 444 (C.C.N.D. Tex. 1886) ("In order to hold and preserve the property and the franchises which make the property valuable it is necessary to operate the same, and the court has appointed receivers to operate and manage the several lines of railway forming the Texas \& Pacific Railway line, running from New Orleans to El Paso.").

75. Fuller, supra note 66, at 381 ("Protective committees were self-constituted groups, formed to represent the various creditor and stock interests of the insolvent carrier. Usually each creditor or equity class had its separate committee.").

76. Importantly, it was the shareholders and creditors who reorganized the railroad, the receiver simply kept it in good operating condition. See James William Moore, Reorganizations under Chapter X, 35 J. NAT'L Ass'N ReF. BANKR. 105, 109 (1961) (“It was not the duty nor the function of the receiver to formulate a plan. Starting, in theory, as adverse litigation the receivership continued in theory to be such with the interested parties-creditors and stockholders-as protectors of their own interests. Self-constituted 'protective committees' arose to represent each of the various creditor and stock interests.").

77. Thacher, supra note 67 , at $37-42,45-49$. There was some doubt about whether priority "new money" financing was appropriate in cases not involving quasi-utilities, like railroads. 1 John Gerdes, Corporate Reorganizations under Section 77B of the BANKRUPTCY ACT $\S 15$ ( $3^{\text {rd }}$ ed. 1936). 
committee's control, and the assets placed in a new corporate shell. ${ }^{78}$ Often, the new company would adopt a similar, although subtlety different name. For example, the Reading Railroad might become the Reading Railway, or vice versa. ${ }^{79}$

Shareholders typically retained their interests in the reorganized railroad only if they paid an assessment, which helped fund the new road's operating cash requirements. ${ }^{80}$ In some cases, the shareholders also received subordinated debt upon payment of the assessment, which protected them in the case of a future receivership. ${ }^{81}$ As one commentator in 1900 wrote:

The right to participate in the benefit of the reorganization comes to stockholders not by virtue of their right as holders of stock, but purely from the grace of the prior lien creditors, who have, in the absence of fraud, the power to give to whom they please an interest in the purchased property. ${ }^{82}$

Shareholders (and unsecured creditors) who did not participate in the reorganization were left with claims against the old corporation, now without operating assets. At most, they might have a proportionate claim to the upset price - essentially the liquidation value - paid to the old railroad as part of

78. Sage v. Cent. R.R. Co., 99 U.S. 334, 339 (1878) ("The amount required is so large usually, that it is beyond the reach of ordinary purchasers . . . the first-mortgage bondholders are the only party that can become the purchasers, and they only, because they need not pay their bid in cash.").

79. Hon. Henry Clay Caldwell, Railroad Receiverships in the Federal Courts, 30 AM. L. REV. 161, 169 (1896).

80. See, e.g., Boyd v. N. Pac. R.R. Co., 170 F. 779, 801 (C.C.E.D. Wash. 1909), aff'd, 177 F. 804 (9th Cir. 1910), aff'd 228 U.S. 482 (1913) (discussing such transactions where the shareholders paid assessment to retain interest in the reorganized railroad). See also Kan. City Terminal Ry. Co. v. Cent. Union Tr. Co., 28 F.2d 177, 188 (8th Cir. 1928) (“'[Because] the [common] stockholders, in order to obtain any participation, were compelled to further invest to the extent of ... 25 per cent ... of the par value of the participating stock, we conclude that there is no doubt as to the fairness of this offer to the unsecured creditor.").

81. See Guar. Tr. Co. of N.Y. v. Mo. Pac. R.R. Co., 238 F. 812, 818 (E.D. Mo. 1916) ("In this case the old stockholders are required to pay in cash 50 per cent. of the par of their holdings. They will receive for their cash payments new 4 per cent. bonds at par. In order, these bonds will come just ahead of the preferred stock. They will be inferior to all the other bonded indebtedness, and their subordinate position in that respect, and their rate of interest, taken together, make it doubtful that they will soon, if ever, be worth par. This will operate as an assessment upon the common stock to the amount of the discount. That the stockholders will be given such bonds for their cash payments is not inequitable to general creditors. They will pay more than they will get in value; but if they paid nothing, and received no bonds, still the relation between them and general creditors would not be disturbed. Besides, the raising of money from some source is imperative, and that raised from the stockholders will be for the benefit of the enterprise as a whole.”).

82. Joline, supra note 53, at 513. 
the foreclosure process. ${ }^{83}$

This is how the receivership process operated in general. In a few rare cases, there was no foreclosure sale, and the receiver simply returned the assets to the railroad. ${ }^{84}$ This happened when the parties were able to work out a fully consensual plan, and thus there was no need to bind dissenters through a sale to a new legal entity. ${ }^{85}$ If dissenters were small in number, sometimes the plan proponents would buy out the dissenters to facilitate such a consensual plan. Alternatively, the old securities might be left outstanding, because in all cases, "the reorganizers must determine whether the expense and practical injustice involved in thus preferring the non-assenting securities is more than counterbalanced" by the benefits of moving forward with the plan. ${ }^{86}$

In modern terms, we would call this latter sort of reorganization a "workout." ${ }^{177}$ The parties became bound to the plan by contract, rather than by judicial action. ${ }^{88}$ As with traditional receiverships, shareholders would agree to pay an assessment to keep their interests in the corporation after the reorganization. ${ }^{89}$ And the railroad also got to keep its original charter, which might be of some value if the legislature had granted special privileges. ${ }^{90}$

As Paul Cravath explained:

A voluntary readjustment may be preceded by a receivership, or even by the institution of foreclosure proceedings, for in case the

83. Samuel Spring, Upset Prices in Corporate Reorganization, 32 HARV. L. REV. 489, 494-95 (1919).

84. Stuart Daggett, Railroad Reorganization 28-29 (1908) (discussing the reorganization of the Baltimore \& Ohio railroad, an example of a consensual reorganization, and noting "[i]t will be remembered that, while provision had early been made for foreclosure, it had been hoped to avoid such a drastic step. Hopes in this respect were fulfilled, and while a number of branch lines were sold, the main stem escaped.").

85. See Paul D. Cravath, The Reorganization of Corporations; Bondholders' and stockholders' Protective Committees; Reorganization Committees; and the Voluntary Recapitalization of Corporations, Lecture Before the Bar Association of the City of New York (March 1, 1916), in Some Legal Phases Of Corporate Financing, Reorganization AND Regulation 153, 211-12 (1917) (explaining that such consensual restructurings were more common in commercial corporations, than railroads).

86. Cravath, supra note 85 , at 212-13.

87. Stephen J. Lubben, Corporate Finance ch. 26 (3d ed. 2021) ("At a basic level a workout is simply an agreement between the debtor-firm and its creditors.").

88. Joline, supra note 53, at 508.

89. DAGGETT, supra note 84 , at 30 ("The common stockholders, instead of being wiped out, have received their common stock in the new company upon paying an assessment, the net amount of which (because of the value of the securities received for such assessment) would not exceed $\$ 5$ or $\$ 6 . ”)$.

90. DAGGETT, supra note 84 , at 30 (noting such a consideration in the 1899 Baltimore \& Ohio reorganization). 
necessary support of security holders eventually is forthcoming, the receivership can be dismissed, or the foreclosure suit abandoned. ... 91

The same result was accomplished in the reorganization of the Texas and Pacific Company in 1887, where the foreclosure sale actually took place but was never confirmed. The consent of the security holders finally made it possible to cancel the old mortgages, dismiss the foreclosure proceedings, create new mortgages, and issue additional stock, thereby preserving the corporation's Federal charter. ${ }^{92}$

The railroad kept its name and was indeed the same corporation. The effects of the reorganization are thus solely the result of the agreement between the creditors and the shareholders, and the subsequent vote by the shareholders to implement the revised reorganization plan. ${ }^{93}$ The receivership in these consensual cases gave the parties sufficient time to come to a deal.

In either the traditional or consensual versions of receiverships, the goal was to implement a deal agreed to by most creditors. The precise contours of that deal were largely left to the parties, as "receivership courts exercised very little supervision over this process. They did not typically concern themselves with either the fairness or the feasibility of the reorganization plan."94

At the turn of the century, the use of receiverships as a flexible reorganization tool was widespread. When the Supreme Court blessed the use of consent receiverships in 1908 and rejected the argument that their highly choreographed nature was "collusively made," the receivership's future as the reorganization tool of choice for larger corporations seemed quite stable. $^{95}$

But there were already signs of discord. ${ }^{96}$ As early as 1881, Justice Samuel F. Miller, in dissent, expressed strong cynicism toward the receivership process which was then just hitting its stride. ${ }^{97}$ In a lengthy

91. Francis Lynde Stetson et al., Some Legal Phrases of Corporate Financing, REORGANIZATION AND REGULATION 210 (1917).

92. Cravath, supra note 85 , at 210-11.

93. See Texas and Pacific, 46 Com. AND FIn. Chron., 320-21 (1888) (noting that a special shareholders meeting had been held the prior week to approve the new mortgages granted under the plan).

94. Vern Countryman, Justice Douglas: Expositor of the Bankruptcy Law, 16 UCLA L. REV. 773, 804 (1969).

95. In re Metropolitan Railway Receivership, 208 U. S. 90, 110 (1908). See also Hollins v. Brierfield Coal \& Iron Co., 150 U.S. 371, 386-87 (1893).

96. JAMES W. Ely, JR., RAILROADS AND AMERICAN LAW 178-79 (2001).

97. Barton v. Barbour, 104 U.S. 126, 137-38 (1881) (Miller, J., dissenting). 
1895 speech, then Circuit Judge William Howard Taft argued that it would be better if receiverships were replaced by federal bankruptcy legislation. ${ }^{98}$ Additionally, a 1905 critic suggested that receivers were routinely flouting the law that governed solvent businesses. ${ }^{99}$

In 1908, one editorialist proclaimed that "[t]he undue prolongation of the receivership in order that the receiver may fatten upon rich fees is a scandalous abuse of trust." ${ }^{100}$ A few years later, the governor of Kansas was less restrained, complaining that, "the attorneys and receivers who participate in this graft seem to have no sense of decency, no feeling of shame when it comes to appropriating money to their own use, which they are presumed to hold as a sacred trust." ${ }^{101}$

In a 1916 speech before the Commercial Law League, Samuel Untermyer ${ }^{102}$ argued that many receivership cases were commenced by corporate officers without the knowledge of their boards, with rampant insider trading on the eve of filing. ${ }^{103}$ Professional fees, he complained, were "easily ten times as large as in any other country and necessarily so because of the complications of the procedure." ${ }^{104} \mathrm{He}$ ultimately concluded that the entire process should be reformed, with railroad reorganizations under the control of the Interstate Commerce Commission, using a process like that used for insolvent banks. ${ }^{105}$

98. William H. Taft, Recent Criticism of the Federal Judiciary, 18 ANNU. ReP. A.B.A. 237, 264 (1895).

99. W. A. Coutts, The Act of Congress Permitting Suits against Federal Receivers Injunctions from State Courts, 39 AM. L. REv. 59, 75 (1905).

100. Receivers, 13 VA. L. Reg. 995, 995-96 (1908) ("At the present time in this state there is one large railroad corporation in the hands of receivers, and it is not amiss to impress upon these officers of the court a lively sense of their duty.").

101. Arthur Kapper [Capper], Law Enforcement, 5 Women LAW. J. 41, 41 (1916).

102. For background, see Untermyer Dead In His $82 d$ Year, N.Y. TimEs, March 17, 1940, at p. 1 .

103. Samuel Untermyer, The Lawyer-Citizen-His Enlarging Responsibilities, Address before the Commercial Law League (July 27, 1916), in Chicago Legal News, Oct. 26, 1916, at 98-99; and in 21 Bull. OF THE COM. L. LeAGUe OF AM., 591-93 (1916).

104. Id.

105. Beginning in 1920, the Interstate Commerce Commission was given a role in receiverships, approving the capital structures of the reorganized railroads. Transportation Act of 1920, 41 Stat. $\S 439$ (1920). As Professors Armour and Cheffins explain:

This legislation expanded the I.C.C.'s jurisdiction over railways to include the power to veto acquisitions that failed to conform to national transportation policy. Correspondingly, an acquirer who successfully bought up the desired percentage of stock could still lose out due to an I.C.C. veto. This likely was a serious deterrent to attempts to gain control by the unsolicited open market buying of shares.

I.C.C. intervention was by no means merely a theoretical possibility. There 
Initially these commentators had limited effect. Indeed, "friendly" consent receiverships were quite common throughout the first three decades of the Twentieth Century. ${ }^{106}$

But slowly, the Supreme Court chipped away at the flexibility of the receivership process, imposing newly discovered rules to defeat previously unnoticed abuses, and consequently slowly decreasing the utility of the process. As early as 1894, the Supreme Court criticized courts who attempted to create something like a bar date and full discharge in consensual - that is, non-foreclosure - reorganizations. ${ }^{107}$

In 1928, the Court attempted to narrow the use of consent receivers, with limited success. ${ }^{108}$ Nonetheless, commentators began to worry:

There can be no doubt that the Supreme Court intended to call a halt to the unlimited use of the friendly receivership; but with occasional exceptions the district judges have continued as before. The continued failure of the district judges to exercise their unquestioned discretion to limit the friendly receivership to proper situations and to eliminate prevalent abuses is indeed unfortunate for it may well lead to a reversal by the Supreme Court of its decision in Re Metropolitan Railway Receivership. ${ }^{109}$

Henry Friendly would write that while "earlier reorganizers had regarded the Boyd case as 'a veritable demon incarnate', reorganizers of the 1920's had far greater justification for considering the dictum in Harkin v. Brundage in a similar light." 110

were at least two instances during the 1920s where the Commission exercised its veto power to block railroad acquisitions after voting control was successfully obtained on the open market.

John Armour \& Brian Cheffins, The Origins of the Market for Corporate Control, 2014 U. ILL. L. REV. 1835, 1847 (2014) (footnotes omitted).

106. Nathan L. Jacobs, Problems in Federal Receivership Jurisdiction, 1 MERCER BEASLEy L. ReV. 29, 44-45 (1932) ("Although the decision in the Metropolitan Railway case met with adverse criticism, the lower federal courts displayed no hesitancy in adopting it to its outermost implications; and abuses of its authority, which will be dealt with later, became prevalent.").

107. Texas \& Pac. Ry. Co. v. Johnson, 151 U.S. 81, 103 (1894) ("Certainly the preservation of general equity jurisdiction over suits instituted against receivers without leave does not, in promotion of the ends of justice, make it competent for the appointing court to determine the rights of persons who are not before it, or subject to its jurisdiction; and the right to sue without resorting to the appointing court, which involves the right to obtain judgment, cannot be assumed to have been rendered practically valueless by this further provision in the same section of the statute which granted it.").

108. Harkin v. Brundage, 276 U.S. 36, 52-53 (1928).

109. Jacobs, supra note 106 , at 46 .

110. Henry J. Friendly, Some Comments on the Corporate Reorganizations Act, 48 HARV. L. REv. 39, 43 (1934) (quoting Paul Cravath with respect to Boyd). 
A line of cases followed, all suggesting that the consent receivership was living on borrowed time. ${ }^{11}$

Boyd itself can be seen as part of the slow drip of caselaw that undermined receiverships, even if today it is known mostly for its purported role in establishing the absolute priority rule. ${ }^{112}$ While Justice Douglas managed to twist the understanding of the case for all time, ${ }^{113}$ its actual holding was understood in the receivership era to be something like "nonparticipating creditors will not be 'discharged' in a reorganization plan that saves old shareholders." 114 That is only indirectly concerned with priority,

111. See e.g., Shapiro v. Wilgus, 287 U. S. 348, 355 (1932) ("The conveyance to the corporation being voidable because fraudulent in law, the receivership must share its fate.”); First Nat. Bank of Cincinnati v. Flershem, 290 U. S. 504, 515 (1934) (explaining that the Supreme Court had only approved receivers in aid of reorganization when dealing with railroads or public utilities where the public interest requires their continued operation).

112. Lawrence M. Bell, Valuation and the Probability of Bankruptcy in Chapter X, 52 Am. BANKR. L.J. 1, 2 (1978); see also Stephen J. Lubben, The Overstated Absolute Priority Rule, 21 Fordham J. CoRP. \& Fin. L. 581, 591 (2016) ("The question, [Douglas] said, was whether the debtor's plan was fair. He concluded it was not because the bondholders 'will be required under the plan to surrender to the stockholders 23 per cent of the value of the enterprise."').

113. In Case v. Los Angeles Lumber Prods. Co., 308 U.S. 106, 116 (1939), Justice Douglas tied Boyd to the so-called "absolute priority rule," as discussed in the text. Interestingly, just a few years earlier, the SEC, of which Douglas was then a member, suggested that payment according the strict liquidation priority (i.e., the absolute priority rule) was not practical in reorganization cases:

"In the give and take of negotiation nice legal priorities of various classes of claims will not be strictly observed. Rather the positions of these various claimants will be traded out in conference, so that only a gross approximation of their strictly legal status will be reached." 1 Securities and Exchange Commission, Study and Investigation of the Work, Activities, Personnel and Functions of Protective and Reorganization Committees 3 (1937).

114. De Forest Billyou, Railroad Reorganization Since Enactment of Section 77, 96 U. PA. L. REV. 793, 809 (1948) ("Long prior to the federal reorganization statutes it was held that a reorganization that did not allow junior creditors to participate in the reorganized company was unfair and inequitable to these creditors if old stockholders were allowed to participate to an extent greater than justified by a new contribution to the reorganized company. It was held also that such a plan, even though consummated, did not preclude these creditors from asserting a debt claim against the reorganized company."); Fuller, supra note 66, at 383 ("The rationale of the decision was that bondholders, who might have purchased the property for themselves alone, could not permit stockholders to obtain an interest in the new company pursuant to an arrangement made before the sale, without also giving every creditor of the old the privilege of participating in the reorganization on a fair and equitable basis."); see also HeNry Winthrop Ballantine, Ballantine's Manual of Corporation law and Practice - A Treatise on the Principles of Corporation Law Practical Directions on Organization Corporate Forms 767 (1930) ("In Northern Pac. Ry. Co. v. Boyd the principle was established that stockholders may not combine with bondholders in a friendly foreclosure sale to freeze out general creditors and obtain an interest in the new corporation 
but the holding did inject another aspect of doubt into the receivership process. ${ }^{115}$

Thus, the receivership's usefulness was well undermined by the Court by the early 1930s. ${ }^{116}$ That, of course, was precisely when the need for corporate reorganization was at its highest. ${ }^{117}$

And receiverships clearly were not without their faults. The ancillary receivership process was extremely cumbersome for industrial companies, who, unlike railroads, did not tend to have their property in contiguous jurisdictions. ${ }^{18}$ Professional fees remained quite high, especially when viewed from a modern (chapter 11) perspective. ${ }^{119}$ In a speech just before the market crash, then professor William O. Douglas broadly argued that "businesses in receiverships are frequently - far too frequently - operated at a loss, thus depleting the estate which otherwise would be available to creditors." 120

Looking back, is it now possible to see that flexibility had a kind of double peak: first in 1908, with the Court's blessing of consent receiverships, and then, after a two-decade wobble, again with the enactment of a codified railroad receivership process in 1933 ("section 77") ${ }^{121}$ - and the receiverships of other, non-rail corporations in 1934 ("section 77B"). ${ }^{122}$

which is derived in whole or in part from their interest in the old, free and clear of the claims of its creditors."); Railroad Reorganization in the Federal Courts: The Unsecured Creditor, 36 HARV. L. Rev. 1007, 1008 (1923) ("But in 1913 the famous Boyd case decided that if the stockholders derive any advantage from the reorganization, the unsecured creditors must be given an opportunity to participate on terms at least as favorable as those offered to the stockholders, or their claims against the property will not be extinguished by the decree.").

115. James N. Rosenberg, New Scheme of Reorganization, 17 Colum. L. Rev. 523, 526 (1917) ("This important case, followed by another decision along the same lines, has subjected reorganizations by foreclosure sale to serious danger of subsequent destructive attack, and indeed is a very nightmare to counsel who have to do with modern reorganizations."); Corporations: Participation of Old Stockholders in Reorganized Corporation After Consent Decree of Foreclosure, 9 CoRnell L. Q. 192 (1924) ("The difficulty is that there is apparently no way by which non-assenting creditors may be compelled to accept a fair and equitable reorganization scheme."); contra Fuller, supra note 66, at 383 ("In the words of one writer, the doctrine of the Boyd case became reasonably domesticated.").

116. This was not uniformly viewed as a bad thing. Felix Frankfurter, Distribution of Judicial Power Between United States and State Courts, 13 CoRnell L. Q. 499, 526 (1928).

117. Sidney Post Simpson, Fifty Years of American Equity, 50 HARV. L. Rev. 171, 191 (1936).

118. Friendly, supra note 110, at 46.

119. Stephen J. Lubben, Railroad Receiverships and Modern Bankruptcy Theory, 89 CoRnell L. REv. 1420, 1452 (2004).

120. Professor Douglas' Address, 3 J. NAT'L Ass'N Ref. BAnKr. 48, 49 (1929).

121. Act of March 3, 1933, ch. 204, 47 Stat. 1474 (1933).

122. Act of June 7, 1934, ch. 424, 48 Stat. 211 (1934). 
It seemed that Congress had killed the receiverships to save them. ${ }^{123}$ But the preservation of the receivership's flexibility, now in the form of a statutory bankruptcy process, was short-lived. And none of these initial reforms addressed the complaint - dating back to the early years of the Twentieth Century - that the receivership process was inherently corrupt. ${ }^{124}$

Perhaps unsurprisingly, these complaints reached fever-pitch with the Great Depression. ${ }^{125}$ For example, New York attorney C.C. Daniels wrote that

The "receivership racket" has taken so much from the stockholders of corporations that the "graft" of the lower courts looks like "chicken feed" by comparison. Receivership allowances, attorneys', auditors' and accountants' fees aggregate huge sumsto say nothing of the sale of assets under conditions that "foreordain" both the purchaser and the price. ${ }^{126}$

This was the atmosphere as corporate reorganization law took a sharp move away from its flexible early days and toward a fairer approach that was less beholden to insiders. ${ }^{127}$

123. Stephen J. Lubben, The Law of Failure 45 (2018). See also Provisions for NonAssenting Classes of Creditors in Bankruptcy Reorganizations, 46 YALE L. J. 116 (1936).

124. Supra note 101. As one commentator summarized:

The reorganization of corporations has been the stepping-stone for and graveyard of professional and judicial reputations and the battleground of conflicting interests and philosophies for many years. This was due in part to the fact that until 1934 there was no statute charting the course for the unwary, but use had to be made of the cumbersome equity or consent receivership. Briefly stated, the objections to that method of reorganization were to the collusive nature of the proceedings, the cumbersome ancillary receiverships, the necessity for sale at an upset price because non-depositors could not be bound, the failure by some courts to exercise adequate control over the plan causing the Supreme Court to cast doubt on the validity of these proceedings, and the reputedly large fees for which courts were criticized, in many instances unjustly because the parties and their representatives would for tactical reasons present a solid front before the Court without objection.

Benjamin Wham, Chapter X, Corporate Reorganizations Chapter X of the Bankruptcy Act, 1939 SEC. CoM. L. 12, 12 (1939).

125. The SEC's multi-volume report on the receivership process, largely overseen by William O. Douglas, was the most prominent example of this literature. David A. Skeel Jr., Welcome Back, SEC, 18 Am. BANKR. InSt. L. Rev. 573, 574 (2010).

126. C. C. Daniels, Receivership Racketeering of Corporation Assets, 3 CoRP. PRAC. ReV. 9, 10 (1931).

127. See Ferdinand Fairfax Stone, The Case of the Ladies' Handbags: A Study in Receivership Procedure, 24 VA. L. REV. 831, 835 (1938) ("Valeria Coriell, claiming that she had no adequate recovery at law, then sued on this note for the appointment of a receiver with the usual allegation of multiplicity of suits and dissipation of assets. It is not pretended that she was more than a convenient non-resident 'dummy,' who lent name and diverse citizenship 


\section{THE NEW DEAL AND THE MOVE TOWARD FAIRNESS}

Section 77, a product of the late Hoover administration, and section $77 \mathrm{~B}$, the general corporate reorganization provision that built off of the railroad-specific section 77, were never warmly embraced by the New Dealers. ${ }^{128}$ And thus, both were revised again before the decade was out. The broad theme of both revisions was to move away from loose, business friendly rules, toward a more formal, less discretionary approach, overseen in each case by independent experts.

\section{A. Railroad Reorganizations - The 1935 Revamp of Section 77}

Section 77 was the first reorganization provision to be revised in the New Deal. While in its original 1933 form it was something of a codified railroad receivership, Congress revamped the process in 1935 to provide for a greater role for the ICC. Moving along the lines that Samuel Untermyer had proposed a couple of decades before, Congress transformed section 77 into a special reorganization proceeding for a regulated industry. ${ }^{129}$

In many respects, the quick move to alter section 77 was not unexpected, inasmuch as the "original Section 77 was drafted and rushed through Congress in the closing days of the Hoover administration." by the time the revision was complete, there was such a change in tone represented by a strong shift from emergency measures to substantial reform

to a suit planned and negotiated by the bank creditors and the debtor himself.").

128. See Roger S. Foster, Conflicting Ideals for Reorganization, 44 YALE L. J. 923, 924 (1935) ("It is not altogether clear how sweeping has been the reformer's victory in the recent changes in reorganization practice.").

129. Other railroad restructuring provisions, often neglected by modern commentators, were also available in this era:

In 1939 Congress added Chapter XV, a temporary measure for Railroad Adjustments to supplement $\$ 77$, and provide a simpler and less drastic means of adjusting the temporary financial difficulties of railroads which were not necessarily insolvent. By its own terms the period within which a petition might be filed under Chapter XV expired July 31, 1940. But a slightly revised Chapter XV was passed in 1942 with, however, a terminating date of Nov. 1, 1945 for the filing of a petition. And in 1948 Congress put railroad adjustments on a more permanent basis by adding $\$ 20 \mathrm{~b}$ to the Interstate Commerce Act.

James William Moore, Reorganizations Under Chapter X, 35 J. NAT'L Ass'N REF. BANKR. 105, 106 (1961).

130. Charles S. Rhyne, Work of the Interstate Commerce Commission in Railroad Reorganization Proceedings under Section 77 of the Bankruptcy Act, 5 GEO. WASH. L. REV. 749, 751 (1937). 
- that the law was almost entirely altered. ${ }^{131}$

In its original form, section 77 innovated the notion of the "debtor in possession," central to today's chapter $11 .^{132}$ The goal was to replace the duplicative receivership process of appointing multiple receivers - often one insider, plus one "independent" party to satisfy receivership tradition - and move straight to the plan negotiation. ${ }^{133}$ In the context of the early 1930s, it was easy to imagine that the railroad might have failed without any culpability on the part of management, and thus the need to replace them with an outsider seemed less urgent. ${ }^{134}$

The court obtained jurisdiction over the entire railroad, eliminating the need for ancillary receiverships. ${ }^{135}$ The debtor proposed a plan and presented it at a hearing before the ICC. ${ }^{136}$ If approved by two-thirds of creditors and the ICC and confirmed by the court, the plan would become binding on all. ${ }^{137}$ Nascent cram-down provisions allowed for the imposition of plans on holdout groups. ${ }^{138}$

After revision in 1935, the debtor-in-possession was gone, and trustees were required in all cases. ${ }^{139}$ The ICC obtained strong powers over the composition of committees, and the right to veto any plan before it went to the court or creditors for consideration. ${ }^{140}$ In true New Deal style, the problem of railroad in financial distress was handed over to the technocrats, and thus became a question of administrative law. ${ }^{141}$

The court's continued involvement in the process was somewhat awkward, to say the least. ${ }^{142}$ But the general trend was clear, flexibility had

131. Id. at 752 .

132. Act of Mar. 3, 1933, ch. 204, § 77(c), 47 Stat. 1467, 1475-77.

133. Churchill Rodgers \& Littleton Groom, Reorganization of Railroad Corporations under Section 77 of the Bankruptcy Act, 33 Colum. L. Rev. 571, 574 (1933).

134. See Fuller, supra note 66, at 385 (explaining that section 77 allowed debtors to remain in possession because of the "theory that financial misfortunes occasioning reorganization may be due neither to inefficiency nor to culpability of the debtor's management").

135. $\$ 77(\mathrm{a}), 47$ Stat. $1467,1474-75$.

136. $I d$. $\$ 77(\mathrm{~d})$, at $1477-78$.

137. Id. $\$ 77(\mathrm{e}),(\mathrm{g}),(\mathrm{h})$, at $1478-80$. Interestingly, the court classified creditors. Id. $\S 77(\mathrm{c})(5)$, at 1476. Contra 11 U.S.C. § 1122 (2018) (modern chapter 11, where the plan proponent, often the debtor, classifies claims).

138. $\$ 77(\mathrm{e}), 47$ Stat. $1467,1471$.

139. Act of Aug. 27, 1935, ch. 774, § 77(c), 49 Stat. 911, 914.

140. Mortimer M. Caplin, Valuation and Earnings in Railroad Reorganization: A Consideration of the Proposed Amendment to Section 77, 27 Va. L. Rev. 769, 778-79 (1940).

141. See generally Leslie Craven \& Warner Fuller, The 1935 Amendments of the Railroad Bankruptcy Law, 49 HARV. L. REV. 1254 (1936) (analyzing the 1935 congressional amendments made to the 1933 bankruptcy statute, specifically to section 77 on railroad reorganizations).

142. See In Re New York, New Haven, and Hartford Railroad Co., 16 F. Supp. 504, 507 
been supplanted by an orderly, fair process, in which all stakeholders would have a chance to participate. ${ }^{143}$

\section{B. Section $77 B$ and the Chandler Act}

Then came the Chandler Act in 1938, which repealed section 77B in its entirety, and replaced it with chapter $\mathrm{X} .{ }^{144}$ The changes here were dramatic. $^{145}$

For the New Dealers, section 77B was too much like what had come before. As E. Merrick Dodd Jr. explained:

Section 77B is . . . a series of ad hoc concessions to the views of the different groups than a carefully worked out compromise between them. To the reorganizers it gives the main reforms for which they have asked, coercive power over minorities and abolition of the sale and of the necessity for ancillary receiverships. These gifts are, indeed, coupled with concessions to the individual creditor or investor which reorganizers are likely to regard as undesirable obstacles to their own control and inconvenient clogs to the smooth and speedy working of the reorganization machinery; but the amendment, taken as a whole, seems more nearly to embody the views of reorganizers than those of any other group. ${ }^{146}$

Like its track-bound predecessor, section 77B promoted the use of a "debtor in possession" model of reorganization, obviating the need to find a trustee or receiver who was both "pure" and able to ably run the distressed business. ${ }^{147}$ Section 77B also contained a provision for what we would today call a prepackaged reorganization plan: "the plan may be accepted not only before the hearing as to its fairness, but even before the institution of

(D. Conn. 1936) (holding that "a District Court of the United States in a proper case may in the exercise of its inherent equity powers approve and enforce a plan of reorganization for a railroad without resort to the fiction of a judicial sale").

143. The Passing of the Consent Receivership, 31 VA. L. REV. 184, 185 (1944) ("Today not only does a standard of the 'fair and equitable' in reorganization remain unaltered, but it is put into effect in the course of the reorganization proceeding itself, where every interest has a chance to be heard; and by the like token, a plan which is confirmed binds everybody.").

144. Act of June 22, 1938, ch.575, 52 Stat. 840, 883-905.

145. As one commentator lamented, "[i]t must be conceded that 77B was not given a fair trial." Benjamin Wham, Chapter X, Corporate Reorganizations Chapter X of the Bankruptcy Act, 1939 ABA SeC. Comm. L. 12, 13 (1939).

146. E. Merrick Jr. Dodd, Reorganization Through Bankruptcy: A Remedy for What?, 48 HARV. L. REV. 1100, 1135 (1935).

147. Jacob J. Kaplan, Corporate Reorganization under Section $77 B$ of the Bankruptcy Act, 6 Law Soc'y J. 879, 881 (1935). 
proceedings under Section 77B." ${ }^{148}$ Committees were regulated but still played a strong role in these proceedings. ${ }^{149}$

Not only could section 77B plans bind dissenting minorities within a class, but the section also included full-throated cramdown provisions that could bind dissenting classes, provided that secured creditors were provided with "adequate protection." 150 Under section $77 \mathrm{~B}(\mathrm{f})$, the court was directed to confirm the plan if satisfied that "it is fair and equitable and does not discriminate unfairly in favor of any class of creditors or stockholders, and is feasible."

But the Securities Exchange Act of 1934 directed the Securities and Exchange Commission to conduct a study of corporate reorganizations and to report thereon to Congress. ${ }^{151}$ This began a multi-year process that led to the ultimate repeal of section 77B, and its replacement with chapter X under the Chandler Act. ${ }^{152}$

Section 77B's flexibility was central to is ultimate downfall. Indeed, the debtor-in-possession and prepack provisions provided the basis for an argument that the insiders were still in charge of restructuring under section 77B. ${ }^{153}$ And thus, the SEC produced a report that tarred the section with a parade of horror stories from the "old days" of the receiverships. ${ }^{154}$

148. Joseph L. Weiner, Corporate Reorganization: Section $77 B$ of the Bankruptcy Act, 34 Colum. L. REv. 1173, 1184 (1934). The author notes that the provision was based on the National Radiator case, where a form of "prepack" was attempted in a receivership, only to be quashed by the Supreme Court (after the enactment of section 77B), which "used rather unflattering language concerning the plan and its protagonists." Id. at 1184-85.

149. Id. at $1185,1188-89$. Some sources indicate that the SEC's power over certificates of deposit under the '33 Act provided an even greater source of committee regulation. See, e.g., Carl B. Spaeth \& J. Frank Friedberg, Early Developments under Section 77B, 30 ILL. L. REV. 137, 144-47 (1935) (arguing that the SEC's view of section 77B(h) was a "more effective" method of holding committees accountable than 77B's provisions on deposit agreements and bondholders' lists).

150. Reorganization under Section 77B of the Bankruptcy Act-1934-36, 49 HARV. L. REV. 1111, 1185-88 (1936). The Murel Holding Corp. case, which developed the concept of "indubitable equivalence," found in today's Bankruptcy Code, is discussed in the foregoing pages, mostly as a leading case rejecting cramdown of a secured class.

151. Securities Exchange Act of 1934, ch. 404, § 211, 48 Stat. 881, 909(1934). The story behind the report is told in John W. Hopkirk, William O. Douglas-His Work in Policing Bankruptcy Proceedings, 18 VAND. L. REV. 663, 666-76 (1965).

152. An initial revision of section 77B was drafted by the newly formed National Bankruptcy Conference. When the SEC's report came along, the NBC draft was revised to reflect most of the SEC's proposed changes. John Gerdes, Corporate Reorganizations: Changes Effected by Chapter X of the Bankruptcy Act, 52 HaRV. L. Rev. 1, 2 (1938).

153. Wham, supra note 145, at 13.

154. E. Merrick Dodd Jr., The Securities and Exchange Commission's Reform Program for Bankruptcy Reorganizations, 38 CoLum. L. Rev. 223, 225 (1938) ("Both Part I and Part II of the [SEC] report are essentially briefs - fair-minded and well documented briefs to be 
In the final installment of the report, issued shortly after the Chandler Act had repealed section 77B, the Commission fired one more broadside at the old section:

Under Section 77B, the management usually remained dominant in the situation during and after reorganization, as was the case in equity reorganizations. It was not held to an account for its stewardship. At the most, its personnel and activities met only casual scrutiny. Good, bad, or in- different management continued in the saddle. ... And it is equally beyond question that the 77B method often promoted and induced superficial reorganizations which left the corporate body with uncured dangerous diseases. ... . So long as the management is in uncontrovertible control, it is futile to expect that a genuine accounting for its past activities can be had, or that its record can be thoroughly analyzed and appraised.

It is absurd to suppose, if the debtor or one of its officers is made the appointee of the court to do these things, that they will be well and thoroughly done. ...

The important function of formulation and negotiation of a plan of reorganization was left to the inside few under the system embodied in Section 77B. ...

This serious deficiency under Section 77B has been corrected in Chapter X of the Chandler Act. . . . ${ }^{155}$

The first step of the new regime was to completely remove management from control of the debtor. ${ }^{156}$ Gone was the debtor-in-possession model, and an independent trustee would now be appointed in every large reorganization case. ${ }^{157}$ The trustee was given "most of the power and control formerly exercised both within and without the proceedings by the debtor, its underwriters, and its largest creditors, in the hope of causing a larger part of

sure - in support of the Commission's recommendations for reform."). Contra Robert T. Swaine, Democratization of Corporate Reorganizations, 38 CoLUM. L. REv. 256, 258 (1938) ("It is unfortunate ... that the SEC Reports lack the objectivity which was to be expected in the light of the scholarly qualities of those primarily responsible for their preparation.").

155. 8 SEC. AND EXCh. Comm'N, Report on the Study and Investigation of the Work, Activities, Personnel and Functions of Protective And Reorganization COMMITTEES: PART VIII 108-11 (1940).

156. Gerdes, supra note 152, at 10.

157. Act of June 22,1938 , ch. $575, \S \S 156,158,52$ Stat. 840,888 . Subsection (4) of $\S$ 158 declared that a person was not disinterested if, for any reason, it appears they had an interest materially adverse to any creditors or stockholders. Debtors were allowed to remain in possession in cases with less than $\$ 250,000$ in debt. Benjamin Wham, Chapter X of the Bankruptcy Act, 5 J. MARSHALL L.Q. 180, 183 (1939). 
the fruits of reorganization to accrue to the benefit of investors." 158

Buttressing the trustee's new role, and an enhanced role for the judge, was an express role for the SEC. That is, the agency played a key role in drafting and promoting a new corporate bankruptcy law that placed itself at the center of American corporate restructuring. ${ }^{159}$ In particular, the Commission was required to opine on the reorganization plan in large cases, and permitted to do so in smaller cases. ${ }^{160}$ It is interesting to note that the SEC's role was advisory, while the ICC's role in post-amendment section 77 cases was more that of a gatekeeper. ${ }^{161}$

Nevertheless, it was clear that the SEC had been given a key role in the process. ${ }^{162}$ In essence, insiders were replaced with three experts: the judge, the trustee, and the Securities and Exchange Commission. ${ }^{163}$ In chapter X,

the debtor plays a minor role, creditors and stockholders are furnished ample information and are given many safeguards, and all major steps in the reorganization are subject to supervision and decisions are to be made by the [district] judge, and not by the

158. Gerdes, supra note 152, at 12.

159. Alfred B. Teton, Reorganization Revised, 48 YALE L. J. 573, 583 (1939); see also Jonathan C. Lipson, The Shadow Bankruptcy System, 89 B.U. L. REv. 1609, 1683 (2009) ("Douglas had a uniquely broad understanding of how reorganizations fit into the larger financial system of his time. It is thus not surprising that he believed the SEC should be the administrator of choice for bankruptcy reorganization, and that disclosure rules should mimic those of the federal securities laws.").

160. See Chandler Act, ch.X, § 172, 52 Stat. 883, 890-91 (1938), amended by 11 U.S.C. (1978) (requiring that, when indebtedness exceeds $\$ 3,000,000$, judges submit plans to the SEC to be examined and reported on).

161. But under section 173 of chapter $X$, the Court could not proceed to confirm a plan until the SEC had either reported or indicated that it did not intend to report, thus giving the SEC a strong say on the pace of the case. Id. § 173.

162. See Jerome Frank, Epithetical Jurisprudence and the Work of the Securities and Exchange Commission in the Administration of Chapter X of the Bankruptcy Act, 18 N.Y.U. L. Q. REV. 317, 322-23, 334 (1941) ("We think we can say that the injection of the Securities and Exchange Commission into the reorganization cases has not substantially delayed the consummation of these proceedings; that in some cases it has demonstrably accelerated it; that in others any delay has been insignificant in amount compared to the benefits derived from the Commission's participation; and that there is generally no feeling on the part of the Bar that the Commission's participation has unnecessarily protracted reorganizations."). See also David A. Skeel, Jr., An Evolutionary Theory of Corporate Law and Corporate Bankruptcy, 51 VAND. L. REV. 1325, 1371 (1998) ("[T] he Chandler act also gave broadranging authority to the SEC to ensure that investors' interests were adequately represented.").

163. Eugene V. Rostow \& Lloyd N. Cutler, Competing Systems of Corporate Reorganization: Chapters X and XI of the Bankruptcy Act, 48 YALE L. J. 1334 (1939) ("Public officers and agencies-the judge, the trustee and the Securities and Exchange Commissionare to dominate the proceedings; management and committees controlled either by management or by the house of issue find the area within which they may act to press their interests correspondingly reduced in size and importance.”). 
[bankruptcy court]. Why the elaborate safeguards?

Largely because it was felt that these were needed to cure the deficiencies of the equity receivership. ${ }^{164}$

Of course, founding a reorganization provision solely on avoiding the sins of the past was probably never the recipe for a lasting process.

At the same time, Congress enacted chapter XI, which was aimed at smaller companies. ${ }^{165}$ Under this chapter, the debtor had control over both its own bankruptcy estate and the plan process. ${ }^{166}$ In theory, secured creditors and shareholders could not have their rights altered by the plan, but they could consent to a modification of their treatment. ${ }^{167}$ From 1952 onward, a chapter XI plan was also not subject to the requirement that it be "fair and equitable," a term the Supreme Court had interpreted to encompass the "absolute priority rule" from liquidations. ${ }^{168}$

In Los Angeles Lumber, Justice Douglas had written that the "fair and equitable," phrase became a term of art used to indicate that a plan of reorganization fulfilled the necessary standards of fairness. Thus, throughout the cases in this earlier chapter of reorganization law, we find the words "equitable and fair," "fair and equitable," "fairly and equitably treated," "adequate and equitable," "just, fair, and equitable" and like phrases used to include the "fixed principle" of the Boyd case, its antecedents and its successors. Hence, we conclude, as have other courts, that that doctrine is firmly imbedded in $\S 77 \mathrm{~B} .{ }^{169}$

Suggesting that "fair and equitable" had acquired "term of art" status in

164. James William Moore, Reorganizations Under Chapter X, 35 J. NAT'L Ass'N ReF. BANKR. 105, 108 (1961).

165. Chapter XI was modeled after the common-law composition of creditors. It was sponsored by the National Association of Credit Men and other groups of creditors' representatives who had experience in representing trade creditors in small and medium sized commercial failures. See Revision of the Bankruptcy Act: Hearing on H.R. 6439 Before the H. Comm. on the Judiciary, 75th Cong., 1st Sess. 31, 35 (1938) (statement of W. Randolph Montgomery, Attorney, National Association of Credit Men) (reintroduced as H.R. 8046 and enacted in 1938).

166. See Peter Van Zandt Cobb, Comment, Initial Financing Restrictions in Chapter XI Bankruptcy Proceedings, 78 Colum. L. Rev. 1683 (1978) (describing the initial steps under chapter XI, where a business may negotiate new plans with creditors while still retaining possession of its assets, although court approval is required).

167. Eugene V. Rostow \& Lloyd N. Cutler, Competing Systems of Corporate Reorganization: Chapters X and XI of the Bankruptcy Act, 48 Yale L. J. 1334, 1353 (1939).

168. Note, Allocation of Corporate Reorganizations Between Chapters X and XI of the Bankruptcy Act, 69 HARV. L. REV. 352, 355-56 (1955).

169. Case v. Los Angeles Lumber Prods. Co., 308 U.S. 106, 118-19 (1939) (footnotes omitted). 
the railroad receivership community probably exaggerated things more than a bit. ${ }^{170}$ Nonetheless, Los Angeles Lumber indicated that the Supreme Court agreed with the SEC's inclination to read the term "fair and equitable" to include something like the absolute priority concept. ${ }^{171}$ In emphasizing the "fixed principles," the Court underlined the degree to which fairness came from strict application of the "rules."

But under chapter XI, shareholders could retain their stakes, even when creditors were not paid in full. ${ }^{172}$

While "although it seems clear that the simplified procedures of Chapter XI were designed for small, privately owned debtors," the chapter was used by many public companies that managed to shoehorn themselves in. ${ }^{173}$ Eventually, this convoluted system of three business reorganization provisions (one for railroads and two for other corporations), operating in conjunction with the traditional liquidation bankruptcy provisions, would need to be rehabilitated. ${ }^{174}$ And with the enactment of the 1978 Bankruptcy Code, it was.

But for about forty years, fairness triumphed over the extreme flexibility of the receivership era. That the fairness era lasted as long as it did was undoubtedly largely due to the healthy state of the American economy in the decades immediately after the Second World War. ${ }^{175}$ In a

170. In the words of Jack Ayer: "Strictly speaking, this is poppycock, and Justice Douglas knew it.” John D. Ayer, Rethinking Absolute Priority After Ahlers, 87 Mich. L. Rev. 963, 975 (1989); see also De Forest Billyou, Comment, "New Directions" A Further Comment, 67 HARV. L. REV. 1379, 1380-81 (1954) (discussing a paper by Professor Walter Blum, which explains how the term "fair and equitable" had not yet acquired a solidified meaning).

171. See Eugene V. Rostow \& Lloyd N. Cutler, Competing Systems of Corporate Reorganization: Chapters X and XI of the Bankruptcy Act, 48 YALE L.J. 1334, 1346 n.55 (1939) ("The S.E.C. is committed to a 'strict priority' view of reorganization draftsmanship."). As noted, the SEC apparently did not always hold that view. See SEC. AND ExсH. Comm'n, supra note 114 (describing how the SEC had previously suggested that the absolute priority rule was impractical).

172. Walter J. Blum \& Stanley A. Kaplan, Affecting Rights to Equity Interests under Chapter XI of the Bankruptcy Act - An Essay Dedicated to Wilber G. Katz, 1972 Wis. L. Rev. 978, 982-83 (1972).

173. Discretion Properly Exercised in Relying on Business Prospects to Allow Chapter XI Arrangement of Large Public Corporate Debtor, 64 CoLuM. L. REv. 155, 157 (1964). See also Melvin Robert Katskee, The Calculus of Corporate Reorganization Chapter Xv. XI and the Role of the SEC Assessed, 45 AM. BANKR. L.J. 171 (1971) (discussing cases which involved deciding between use of chapter X or XI for various companies).

174. Cf. In re Herold Radio \& Elecs. Corp., 191 F. Supp. 780, $786-87$ (S.D.N.Y. 1961) (discussing an array of questions that arise from a lack of case law clarity regarding Chapters $\mathrm{X}$ and XI, none of which are "decisive" on their own, leading to the need for "a rigid formula" to be applied instead).

175. See Robert Skidelsy, Money and Government: The Past and Future of ECONOMICS 154-62 (2018) (discussing the post-war to 1970 boom in developed economies). 
less vibrant economy, the need for a workable corporate insolvency system would have been more apparent, much sooner.

\section{1978 AND THE RETURN OF FLEXIBILITY}

Although chapter X was largely considered to have died of its own complexity, with chapter XI used whenever possible, it is remarkable how many leading commentators continued to praise the basic concept of chapter $\mathrm{X}$, even as an effort to reform the Bankruptcy Act began to take shape. ${ }^{176} \mathrm{In}$ the early Sixties, James William Moore remarked that chapter X, while not perfect, was still much better than the old equity receivership system. ${ }^{177}$ And Benjamin Weintraub and Harris Levin thought that the revision of the Bankruptcy Rules in the early 1970s had taken care of most of the problems. ${ }^{178}$ That the Rules constituted almost a complete rewriting of chapter X might give us some pause about the true state of chapter X. ${ }^{179}$

And there were other hints that all was not quite right. A 1961 speech by the SEC's Chicago restructuring chief defended chapter X by reference to the recently completed reorganization of Inland Gas Corporation, which took more than thirty years. ${ }^{180}$ In the same remarks, he also lamented that

176. As explained by one attorney,

I think that the predilection for Chapter XI is based upon the experience of the creditor community which has come to the recognition that Chapter $\mathrm{X}$ is cumbersome, bureaucratic, time consuming and expensive. On the other hand, creditors recognize that Chapter XI affords a quicker, more intelligent and less expensive way to solve an economic problem.

Peter F. Coogan, George W. Bermant \& Herman L. Glatt, Panel Discussion: The Problems of the Sinking Ship, 31 Bus. LAW. 1371, 1378 (1976).

177. James William Moore, Reorganizations Under Chapter X, 35 J. NAT'L Ass'N ReF. BANKR. 105, 112 (1961).

178. Benjamin Weintraub \& Harris Levin, Chapter VII (Reorganizations) as Proposed by the Bankruptcy Commission: The Widening Gap Between Theory and Reality, 47 AM. BANKR. L.J. 323, 323-24 (1973). 28 U.S.C. § 2075 (1964) (current version at 28 U.S.C. § 2075 (2018)) provided that:

The Supreme Court shall have the power to prescribe by general rules, the forms of process, writs, pleading, and motions, and the practice and procedure under the Bankruptcy Act ... provided the rules do not abridge, enlarge, or modify any substantive right.... All laws in conflict with such rules shall be of no further force or effect after such rules have taken effect.

179. See William H. Lake, The Chapter X Bankruptcy Rules: Procedural Reform for the Reorganization of a Corporation, 51 L.A. B.J. 493, 493 (1976) ("The Act is largely replaced by the Rules since many of the provisions of Chapter X are procedural in nature.").

180. See J. Kirk Windle, Obstacles to Successful Reorganization, 36 J. NAT'L Ass'N ReF. BANKR. 12, 12-13 (1962) (describing how a lack of early approval of a compromise allowed 
"creditors and stockholders who have large sums of money at stake display almost complete lack of interest in the reorganization proceedings," implored the attorneys in the audience to become "reorganization minded. ${ }^{182}$

In 1972, two leading restructuring attorneys, while generally sympathetic to chapter $\mathrm{X}$, conceded that

Most complaints about corporate reorganization center around time and money. It takes too long and it costs too much.

It is true that the elapsed time between the filing of the petition and the closing of the case is measured in years rather than months. This results from three basic causes. First, the Chapter is structured with many safeguards designed to protect the public, the investors and the creditors. The court, the stockholders, and the creditors must be informed before they can act or vote intelligently. They are informed by the Section 167 Report which is disseminated only after the most careful investigation by the trustee, aided by the Securities and Exchange Commission. This takes time. The plan takes time to prepare. Creditors must be classified, and hearings on this facet alone may require many months. Valuation is, perhaps, the court's most critical function, and this valuation is time-consuming. After all, the debtor may have taken several years or even several decades to arrive at the trouble it is in. It can hardly be expected that the accumulated problems resulting from years of inept management or misfortune can be quickly solved. The second reason for delay is that many complex and conflicting rights are involved. A not untypical case may involve priorities as between tax liens, consensual liens, mechanic's and materialmen's liens, overlapping security interests with consequent marshalling problems, outstanding debentures which are sub-ordinated to one class of creditors and not to another, and problems of equitable subordination. This tangled skein requires time to unravel. Third, plan acceptance is based on plan approval by a two-thirds majority in amount of the creditors in each affected class, and there may be many such classes. The hard bargaining between the various classes and the trustee which necessarily goes into the formulation of an acceptable plan makes delay inevitable. But no one suggests that the democratic process should be abandoned and "cram-down" provisions substituted. ${ }^{183}$

Inland Gas to payback millions to creditors over the thirty-year time span, ultimately saving "thousands of public investors").

181. Id. at 17.

182. Id.

183. William J. Rochelle Jr. \& Jack H. Balzersen, Recommendations for Amendments to Chapter X, 46 AM. BANKR. L.J. 93, 94-95 (1972). 
By the end of the decade, a return to cramdown was indeed deemed the apt solution. $^{184}$

As early as 1940, Florence De Haas Dembitz, then an attorney with the Reconstruction Finance Corporation's railroad division (and who had previously practiced before the ICC), noted that railroad reorganizations under section 77 were painfully slow, a result she traced to both an overworked ICC staff and a process that was overly focused on litigation, in place of negotiation. ${ }^{185}$ In a similar vein, in 1943, Robert Swaine complained that section 77 turned business problems into bureaucratic tasks and formal litigation, and consequently delayed resolution of financial distress. ${ }^{186}$ Somewhat later, Edwin S. Sunderland echoed these complaints, placing most of the blame on the ICC and its laborious procedures. ${ }^{187}$ By the time the Penn Central sank into a section 77 proceeding in 1970, it was well-recognized that section 77 was not really a workable solution for failure outside the context of the Great Depression. ${ }^{188}$

As summarized by one commentator:

... section 77 is inadequate to deal with the present situation. It neither provides the tools nor creates the circumstances necessary for the successful reorganization of railroads under today's conditions. This is not to criticize those who drafted section 77 and the 1935 amendments ... However, as things stand today section 77 is too limited in its scope, too formal in its approach, and too circumscribed in its procedures to permit the formulation of a sound plan of reorganization under contemporary circumstances. ${ }^{189}$

184. See 11 U.S.C. $\S 1129$ (b) (Supp. I 1976)(current version at 11 U.S.C. $\S 1129$ (b) (2018)) (requiring that courts confirm plans that meet specified requirements, do "not discriminate unfairly," and that are "fair and equitable," even if said plans have not been accepted by all claimants).

185. See generally Florence de Haas Dembitz, Progress and Delay in Railroad Reorganizations Since 1933, 7 LAw \& CONTEMP. PROBS. 393, 407, 411-16 (1940) (discussing factors that delayed reorganizations, including "Legal Questions" and an "Overburdened Interstate Commerce Commission").

186. Robert T. Swaine, A Decade of Railroad Reorganization Under Section 77 of the Federal Bankruptcy Act, 56 Harv. L. Rev. 1037, 1056-58 (1943). See also Joseph C. Simpson, Comments on the Railroad Reorganization Provisions of the Bankruptcy Act of 1973, 30 Bus. LAw. 1207, 1216-17 (1975) (mentioning several reorganizations that took years to complete and describing the lengthy back and forth process of hearings, planning, and approvals required for reorganization).

187. Edwin S. S. Sunderland, Suggestions for Improvement in Section 77 of the Bankruptcy Act, 14 Bus. LAW. 487, 495, 498-99 (1959).

188. Steven S. Elbaum, Division of Jurisdiction between Section 77 Reorganization Courts, 39 BRook. L. Rev. 839, 857 (1973).

189. Richard J. Barber, Railroad Reorganization, Section 77, and the Need for Legislative 
Indeed, ultimately Congress adopted a special "one off" bankruptcy procedure for the Northeastern railroads. ${ }^{190}$ In doing so, the legislators at least implicitly indicated their agreement with the critics. ${ }^{191}$

In a similar vein, the 1973 Commission on Bankruptcy Laws of the United States argued that "the defects in section 77 stem from divided responsibility and an elaborate procedure which assumes that the time available in which to effect a cure is infinite. ${ }^{, 192}$ But the proposed solution was to make section 77 more like chapter X, with the ICC supporting the court, instead of operating in parallel with it. ${ }^{193}$

On the general business reorganization side, the Commission proposed a new reorganization chapter (chapter VII) in which the "flexibility of present Chapter XI is retained to the extent compatible with the interests of creditors, but the protective features of present Chapter $\mathrm{X}$ are generally made applicable, with the exception of the 'absolute priority rule,' which is substantially modified." 194 This never enacted chapter would have also retained many features of the Chandler Act as well, including a presumption of trustees in larger cases, and government oversight in cases involving public securities (albeit by a new bankruptcy administrator, instead of the SEC). ${ }^{195}$

Even the need for this seemingly modest set of reforms was questioned. Two leading practitioners argued that:

Amendments beneficial to Chapters X and XI can be effected within the confines of those chapters without the necessity of

Reform, 21 UCLA L. REv. 553, 554 (1973).

190. In re Penn Cent. Transp. Co., 384 F. Supp. 895, 902-904 (Reg'l Rail Reorg. Ct. 1974) ("While the Act is titled a reorganization statute, its drafters acknowledged that the northeastern railroad problem cannot be solved simply by resort to the traditional procedures available under $\S 77$ of the Bankruptcy Act and the Interstate Commerce Act."). See Stephen J. Lubben, PROMESA and the Bankruptcy Clause: A Reminder About Uniformity, 12 BROOK. J. CORP. Fin. \& COM. L. 53, 57 (2017) (stating that the Regional Rail Reorganization Act created a special bankruptcy process for Northeastern railroads).

191. See Oscar Couwenberg \& Stephen J. Lubben, Not A Bank, Not A SIFI; Still Too Big to Fail, 35 EMORY BANkr. Dev. J. 53, 79 (2019) (discussing Lockheed and Chrysler's financial distress before the adoption of a modern corporate bankruptcy procedure). One critic argued that section 77 was no longer fit for modern railroad problems, and suggested that "the whole question of railroad reorganization be separated from the consideration of reform of the Bankruptcy Act and spotlighted as a transportation problem that calls for immediate congressional examination aimed at producing specifically tailored legislation," as Congress ultimately did. Barber, supra note 189 , at 554 .

192. 1 RePORT OF COMMISSION ON BANKRUPTCy LAWS OF UNITED STATES 29 (1973).

193. Id. at 30.

194. Id. at 237.

195. Walter W. Miller Jr., Bankruptcy Code Cramdown under Chapter 11: New Threat to Shareholder Interests, 62 B.U. L. Rev. 1059,1072-73 (1982). 
destroying a thirty-five year old system which has responded well to the needs of the parties whose interests are at stake. Indeed, the present problems are not such as require total restructuring. ${ }^{196}$

In short, as late as 1973, outside the specific issue of railroad insolvency, there was no clear consensus that business bankruptcy was in need of reform. Indeed, the so-called "Judge's Bill," a proposed revision to the Commission's bankruptcy reform bill, expressly retained chapters X and XI. ${ }^{197}$

But the American economy looked increasingly wobbly in the mid1970s, and the Bankruptcy Act was tested and found wanting. As summarized by Professor Minsky:

Not only was income declining rapidly and the unemployment rate exploding, but virtually each day saw another bank, financial organization, municipality, business corporation, or country admit to financial difficulties. For example, in October 1974 the multibillion-dollar Franklin National Bank of New York failed (at the time it was the largest American bank ever to fail), and in early 1975 the billion-dollar Security National Bank of New York was merged to prevent over failure. During 1974-75 more banks failed, and more assets were affected than in any period since World War II. Moreover, the Real Estate Investment Trust (REIT) industry, with some $\$ 20$ billion in assets, experienced a severe run that led to many bankruptcies and work-outs.

In addition, 1975 was marked by New York City's financial crisis, the failure of W.T. Grant and Company, the need for Consolidated Edison to sell assets to New York state in order to meet payments commitments and the walking bankruptcy of Pan Am. ${ }^{198}$

And perhaps as a result, between the failure of both the Commission and Judge's bills, and the enactment of the 1978 Bankruptcy Code, there developed a consensus that the two general reorganization chapters ${ }^{199}$ should

196. Weintraub \& Levin, supra note 178, at 323.

197. J. Ronald Trost \& Lawrence P. King, Congress and Bankruptcy Reform Circa 1977, 33 Bus. Law. 489, 493 (1978). The alternate bill was proposed by the National Conference of Bankruptcy Judges.

198. Hyman P. Minsky, Stabilizing an Unstable Economy 15 (1986) (2008 McGrawHill edition). The W.T. Grant bankruptcy was the biggest to that point, save for Penn Central's. Pan Am would file an actual bankruptcy in the 1980s, after the enactment of the new Bankruptcy Code.

199. Three if you counted the rarely used Chapter XII. Michelle M. Harner, Rethinking Preemption and Constitutional Parameters in Bankruptcy, 59 WM. \& MARY L. REV. 147, 162 (2017). 
be combined into a single chapter. ${ }^{200}$ The primary argument seemed to be that creditors and debtors would benefit from being able to "mix and match" aspects of both chapters X and XI: for example, allowing the debtor to stay in possession, while also imposing the absolute priority rule. ${ }^{201}$

From these relatively tenuous beginnings began the process which returned corporate bankruptcy, and corporate reorganization in particular, to a state of flexibility. The 1978 Bankruptcy Code not only consolidated reorganization chapters, but importantly removed the requirement of a trustee in certain classes of cases, namely those involving large or widely held debtors. ${ }^{202}$ That is, the old section 77 and 77B concept of the debtor in possession - which had been kept alive in chapter XI - was now back in full.

The SEC was taken out of the center of reorganization and, perhaps most importantly, its role was not taken over by any other expert body. ${ }^{203}$ Rather, the New Deal faith in administrative expertise seemingly died, at least with regard to bankruptcy, with the 1978 Code. ${ }^{204}$

In a nutshell:

A general and basic concept of the new chapter 11 is the recognition that the parties involved should be able to negotiate a plan even to the point that those holding senior interests allow junior interests to realize some distribution and, if such a plan is acceptable based on informed consent, the court should not be hamstrung by an inflexible standard in determining whether the plan should be confirmed. ${ }^{205}$

Not all were in favor of the change, ${ }^{206}$ but the door to a more flexible

200. Indeed, the National Conference of Bankruptcy Judges and the National Bankruptcy Conference identified this as one of a handful of points of agreement. Trost \& King, supra note 197 , at 494 .

201. Id. at 529-30.

202. For an overview, see J. Ronald Trost, Business Reorganizations under Chapter 11 of the New Bankruptcy Code, 34 Bus. Law. 1309 (1979).

203. Sarah Paterson, Market Organisations and Institutions in America and England: Valuation in Corporate Bankruptcy, 93 CHI.-Kent L. Rev. 801, 815 (2018).

204. See John Wm. Butler, Jr., Chris L. Dickerson, \& Stephen S. Neuman, Preserving State Corporate Governance Law in Chapter 11: Maximizing Value Through Traditional Fiduciaries, 18 AM. BANKR. INST. L. REV. 337, 340-42 (2010) (stating that various problems existing prior to the 1789 bankruptcy system, compelled Congress to create a single reorganization chapter, Chapter 11); see also Kelli A. Alces, Enforcing Corporate Fiduciary Duties in Bankruptcy, 56 U. KAN. L. REv. 83, 84-85 (2007) (emphasizing the importance of the appointment of a Chapter 11 trustee as a remedy for creditors who have serious grievances about a debtor's estate management).

205. Lawrence P. King, Chapter 11 of the 1978 Bankruptcy Code, 53 Am. BANKr. L.J. 107, 108 (1979).

206. Arthur L. Moller, Chapter 11 of the 1978 Bankruptcy Code or Whatever Happened to Good Old Chapter XI, 11 ST. MARY's L.J. 437, 438 (1979) (“'One of the most drastic, and 
approach to business bankruptcy was open once again.

\section{MODERN BUSINESS BANKRUPTCY: TOO MUCH FLEX?}

In the forty years since the enactment of the current Code, chapter 11 moved from a debtor-dominated system, ${ }^{207}$ to one dominated by senior lenders, ${ }^{208}$ to eventually settle, most recently, on a system where key parties, both debtors and creditors, frequently adopt a deal well before initiating the bankruptcy process through a "restructuring support agreement." ${ }^{209}$ In doing so, reorganizations are now structured with but a slight essence of the Bankruptcy Code, and the framework it sets forth. ${ }^{210}$ But there are signs that this new, ultra-flexible approach - where any deal agreed to by large majorities of creditors seems likely to be approved - may have gone too far. $^{211}$

After an initial decade marked by strong debtor control combined with seemingly endless extensions of the debtor's exclusive right to file a plan, senior creditors eventually learned how to play the chapter 11 game too. ${ }^{212}$ Using the strong powers given to secured creditors under the Code, combined with the ability to force asset sales under section 363 in place of chapter 7 liquidations in situations where reorganizations were making little progress, lenders increasingly compelled asset sales before plan formation. ${ }^{213}$

probably the least successful, provisions of the new Bankruptcy Code is the consolidation of Chapters VIII, X, XI, and XII of the Bankruptcy Act into a single chapter, chapter 11 of the Code.").

207. Michelle M. Harner, The Search for an Unbiased Fiduciary in Corporate Reorganizations, 86 NotRe DAme L. ReV. 469, 485 (2011); see also Lawrence Ponoroff, Bankruptcy Preferences: Recalcitrant Passengers Aboard the Flight from Creditor Equality, 90 Aм. BANKR. L.J. 329, 331-32 (2016) (stating that the Bankruptcy Reform Act of 1978 was the most debtor-friendly U.S. bankruptcy law ever enacted).

208. David A. Skeel, Jr., Creditors' Ball: The "New" New Corporate Governance in Chapter 11, 152 U. PA. L. REv. 917, 931-33 (2003).

209. See generally Douglas G. Baird, Bankruptcy's Quiet Revolution, 91 Am. BANKR. L.J. 593, 593 (2017) (discussing how a restricting support agreement can interfere with the flow of information needed to apply Chapter 11's substantively).

210. See David A. Skeel, Jr. \& George Triantis, Bankruptcy's Uneasy Shift to A Contract Paradigm, 166 U. PA. L. REV. 1777, 1809 (2018) (discussing the benefits of restructuring support agreements).

211. Jonathan C. Lipson, The Secret Life of Priority: Corporate Reorganization After Jevic, 93 WASH. L. REV. 631, 639 (2018).

212. See generally Kenneth M. Ayotte \& Edward R. Morrison, Creditor Control and Conflict in Chapter 11, 1 J. Legal ANALYsis 511 (2009) (arguing that senior lenders exercise significant and pervasive control over the bankruptcy process).

213. Melissa B. Jacoby \& Edward J. Janger, Ice Cube Bonds: Allocating the Price of Process in Chapter 11 Bankruptcy, 123 YALE L.J. 862, 877-78 (2014). 
By the end of the 1990s, such 363 sales were routine, especially in mid-cap cases. $^{214}$

But powerful though secured creditors are - with control over cash, and special rights under the Code $^{215}$ - the Bankruptcy Code, even in its modern form, balances power in ways that it makes it hard to act alone. ${ }^{216}$ As a result, in recent years, it has become common for chapter 11 cases to coalesce around a restructuring support agreement, or RSA. ${ }^{217}$

In the prototypical cases, the RSA will be negotiated at first by the debtor and one or more funds that hold a sizable portion of the outstanding debt. Often, the secured senior lenders will be largely or entirely unharmed by the proposed reorganization, and thus the action happens in the negotiations between the next tier of debtholders and the debtor's management. Once a deal is reached between the initial creditor group and the debtor, the deal is frequently opened up to other investors, with retail investors excluded to avoid securities law complications.

Thus, when the chapter 11 case actually commences, the plan outlined in the RSA will often have tremendous levels of support, far beyond those required by the Code. The real question, however, is how much of this support comes from creditors who perceive a lack of real options. That is, the deal reflected in the RSA might not be all the creditor is entitled to, but taking the deal still might be better than an expensive and likely futile effort to disrupt the RSA. ${ }^{218}$ Creditors at the margin can be swayed with various fees or bonuses granted to those who support the plan before a set deadline. ${ }^{219}$

These RSAs, combined with better-known techniques like gifting plans and structured dismissals, mean that the "fixed principles" once championed

214. For an example which the author was involved in, see Motion for Order [A] [i] Approving Auction Procedures with Respect to Proposed Sale of Substantially All Assets of Debtors' Business Units, [ii] Scheduling Hearing on Approval of Sale, [iii] Approving Form and Manner of Notice of Sale, [iv] Approving Break-up Fee and [B] [i] Approving Sale of Substantially All Assets of Debtors Business Units Free and Clear of All Liens, Claims, Interests, and Encumbrances and [ii] Authorizing Assumption and Assignment of Certain Executory Contracts and Unexpired Leases, and [C] Granting Related Relief, In re Brazos Sportswear, Inc., 99-142 (PJW) (Bankr. D. Del.) (docket no. 264).

215. Including the right to receive various fees, the right to adequate protection, and the right to credit bid. See 11 U.S.C. $\S \S 362(d)(1), 363(k), 506(b)$ (2018).

216. Stephen J. Lubben, The "New and Improved" Chapter 11, 93 Ky. L.J. 839, 857 (2005).

217. See Oscar Couwenberg \& Stephen J. Lubben, Private Benefits Without Control? Modern Chapter 11 and the Market for Corporate Control, 13 BRooK. J. CoRP. Fin. \& CoM. L. 145, 166 (2018) (explaining the use of RSAs "to move key aspects of the restructuring deal out of the purview of the court.").

218. Id.

219. Id. at 165-66. 
by the New Dealers, ${ }^{220}$ which importantly provided a formal structure to reorganizations, are no longer present, and that corporate bankruptcy has now reached a point of extreme flexibility. Indeed, chapter 11 as presently practiced is now at least as flexible as reorganization under the old receivership regime. ${ }^{221}$

But there are also signs of a developing backlash. The automotive bankruptcy cases of 2009 present this most clearly. Putting to one side those objections that seem to have been targeted specifically against the Obama Administration, objections to the use of section 363 sales to push deals that arguably could not be achieved under section 1129 illustrate a general concern that corporate bankruptcy has become too flexible. ${ }^{222}$

And we see this theme percolating up in a variety of contexts. Questions about the ability of secured lenders to drive the bankruptcy process, ${ }^{223}$ challenges to the deals that big creditor groups work out among themselves, ${ }^{224}$ and even challenges to the lack of shareholder participation in

220. Case v. Los Angeles Lumber Prods. Co., 308 U.S. 106, 118-19 (1939) (footnotes omitted).

221. William W. Bratton \& David A. Skeel, Jr., Bankruptcy's New and Old Frontiers, 166 U. PA. L. REV. 1571, 1582 (2018).

222. See, e.g., Ralph Brubaker \& Charles Jordan Tabb, Bankruptcy Reorganizations and the Troubling Legacy of Chrysler and GM, 2010 U. ILL. L. REV. 1375, 1378 (2010) (expressing concern about the use of $\S 363$ sales in the GM and Chrysler bankruptcies to avoid the Bankruptcy Code's detailed plan confirmation rules for reorganizations).

223. Melissa B. Jacoby \& Edward J. Janger, Tracing Equity: Realizing and Allocating Value in Chapter 11, 96 Tex. L. Rev. 673, 706 (2018). See also Michelle M. Harner, The Value of Soft Variables in Corporate Reorganizations, 2015 U. ILL. L. Rev. 509, 519 ("Secured lenders may favor a quick sale, either to liquidate their positions as quickly as possible or to obtain control of the future direction of the company."); Melissa B. Jacoby, Corporate Bankruptcy Hybridity, 166 U. PA. L. REv. 1715, 1730 (2018) (arguing that lenders have gradually shaped chapter 11 to reduce public standards and oversight); Edward J. Janger, The Logic and Limits of Liens, 2015 U. ILL. L. REV. 589, 608 (listing aspects of bankruptcy practice that allow secured creditors "to undercut the value maximizing and equality oriented policies of the code"); Juliet M. Moringiello, When Does Some Federal Interest Require a Different Result?: An Essay on the Use and Misuse of Butner v. United States, 2015 U. ILl. L. REV. 657, 658-59 (mentioning the American Bankruptcy Institute's concern that Chapter 11 no longer effectively balances its primary goals because it gives secured creditors "excessive control over business reorganizations"); Jay Lawrence Westbrook, The Control of Wealth in Bankruptcy, 82 TEx. L. REV. 795, 826-27 (2004) (noting the intent of Congress to create a system that encourages a combination of secured credit, unsecured credit, and equity financing, as opposed to favoring secured credit alone).

224. Vincent S.J. Buccola, The Janus Faces of Reorganization Law, 44 J. CoRP. L. 1, 16 (2018); Sally McDonald Henry, Chapter 11 Zombies, 50 InD. L. REV. 579, 580 (2017); accord Alessandra Allegretto, Overcoming Creditor Misfortune Creatively: Structured Dismissals in Chapter 11 Bankruptcies, 36 J.L. \& Com. 239, 248 (2018) (discussing the use of structured dismissals which allow parties to broker their own solutions to Chapter 11 bankruptcies). 
modern chapter $11^{225}$ all suggest a growing discomfort with the new shape that corporate bankruptcy has taken. ${ }^{226}$ While these largely academic complaints have found little traction in the bankruptcy courts, there are growing indications that the appellate courts are more sympathetic.

Thus, we see opinions constraining the more extreme versions of flexibility. ${ }^{227}$ The Supreme Court's Jevic opinion is simply the most highprofile version of this trend. ${ }^{228}$

The door is thus open for a retrenchment toward a "fairer" corporate bankruptcy system. $^{229}$ But given that the primary past example of such a move - the Chandler Act - was somewhat less than successful, in the next and final section, I consider how the lessons of history, reviewed in this paper, might better inform the balance between fairness and flexibility. The move toward more fairness need not inherently mean a fairness-heavy approach.

\section{THE WAY FORWARD}

Modern chapter 11 rejoices in cases that are tidy. Tidiness is often measured from the debtor or lead lender's perspective, although quite often bankruptcy courts also appreciate this perspective as well.

Nothing is tidier than a case that commences with large majorities of creditors supporting a plan set forth in an RSA. Regrettably, courts have shown little willingness to consider how those remarkable majorities were obtained. For example, did creditors feel pressured to sign onto the RSA because the deal was going to go through in any event, and those who did

225. E.g., Diane Lourdes Dick, The Bearish Bankruptcy, 52 GA. L. Rev. 437, 467-69 (2018) (exploring how shareholders struggle in Chapter 11 bankruptcies and advocating for equity committees to negotiate with the debtor and its senior creditors).

226. Jonathan C. Lipson, Braucher's Business: Foreseeing Relational Contract Bankruptcy, 58 ArIZ. L. REV. 173, 191 (2016); see also Lynn M. LoPucki, Changes in Chapter 11 Success Levels Since 1980, 87 TEMP. L. Rev. 989, 989-92 (2015) (finding a declining success rate of Chapter 11 bankruptcies since 1980).

227. E.g., In re DBSD N. Am., Inc., 634 F.3d 79 (2d Cir. 2011) (rejecting "gift" plans). But see In re Nuverra Environmental Solutions, Inc., 590 B.R.75, 90 (D. Del.2018) (holding that disparate "gifts" from senior secured creditors to two different classes of unsecured creditors did not unfairly discriminate against the least-favored class and did not violate the "absolute priority" rule).

228. See Jonathan C. Lipson, Controlling Creditor Control: Jevic and the end(?) of LifeCare, 27 NORTON J. BANKR. L. \& PRAC., 563-64 (2018) ("Although Jevic does not forbid structured dismissals, it does establish guardrails for their use.").

229. See Michelle M. Harner, Rethinking Preemption and Constitutional Parameters in Bankruptcy, 59 WM. \& MARY L. REV. 147, 212 (2017) (noting that prominent figures like the American Bankruptcy Institute have called for the reform of Chapter 11). 
not sign were relegated to a lower return? Were creditors obliged to consider the RSA under severe time pressure, and then locked into their support by an agreement that provides for specific performance and application of non-US law? $?^{230}$

More broadly, the move toward quick 363 sales, complex DIP loan agreements that grant lenders extensive control, and the increasing complexity of capital structures (admittedly, not strictly speaking a bankruptcy issue), have made chapter 11 ever more an "insiders" game. ${ }^{231}$ First day motions, with their foundation in a host of ancient receivership law of dubious applicability, are undoubtedly needed to achieve chapter 11's basic goal of maintaining a going concern. But first day motions also allow the debtor (and the DIP lender, who provides the cash) an ability to pick winners and losers.

That is, chapter 11 is increasingly subject to the same sort of criticism once leveled at the receiverships: namely, that insiders benefit by extracting wealth from small claimants. Some of this is by design: the very move from the rigid chapter $\mathrm{X}$ to chapter 11 was inherently about making corporate reorganization more like other corporate transactions, where the parties would negotiate and reach a "deal." The real charge, at heart, is that the fear of paternalism has gone too far, and courts have become so tolerant that they let the dealmakers run away with the show.

The easy answer to these excesses is to urge a rededication to the "rules." Discretion should be reduced, and in its place, a more formal structure, applicable to all creditors regardless of size of stake, set forth in its place. Typically, this involves a strong belief that the rule of liquidation the so called "absolute priority rule" - should make a more frequent, and more vigorous, appearance in modern chapter 11 .

One problem with this easy equation of the "rules" with the ill-named absolute priority rule is that the current Bankruptcy Code only applies the latter rule in cases of cramdown, when a plan is being imposed on a dissenting class, and then only in the specific case of unsecured creditors. ${ }^{232}$ In cases where the plan is "consensual" - that is, approved by the requisite minority, there still might be a sizable minority that does not truly consent the absolute priority rule has no applicability. ${ }^{233}$ At the point of a 363 sale

230. Couwenberg \& Lubben, supra note 217, at 165-67.

231. Douglas G. Baird \& Robert K. Rasmussen, Antibankruptcy, 119 YALE L.J. 648, 686 (2010).

232. 11 U.S.C. $\S 1129$ (b) (2018).

233. Namely, under Chapter 11, a class accepts a plan (and thus the absolute priority rule does not apply), if a simple majority in number, and two-thirds in amount, consent. 11 U.S.C. $\S 1126(\mathrm{c})$; see also $\S \S 1129(\mathrm{a})(8)$, (a)(10). As a consequence, $49 \%$ of creditors by number 
or a "structured settlement," we do not know which type of plan might arise in the, often hypothetical, future.

Such worries did not detain the Supreme Court in Jevic, which nonetheless held that a structured settlement must follow absolute priority. ${ }^{234}$ Many critics of the auto bankruptcy 363 sales also seemed to think the absolute priority rule should apply to the terms of a 363 sale, conducted well before any plan was on the table. In short, although many suggest the absolute priority rule and other more rule-based reforms of current flexible reorganization practice come from a more formal reading of the Code, the opposite is actually true. Nonetheless, more rules and more court oversight of adherence to the rules is often seen as a good thing by a wide range of critics, all of whom approach modern chapter 11 for a range of viewpoints.

The trick is that it has long been recognized that the absolute priority rule does not really work, at least in a formal sense, with a system designed to save operating businesses. ${ }^{235}$ This, in large part, is because the rule relates to liquidation, which has little to do with ongoing operations.

In some sense the absolute priority rule has become like the old GlassSteagall Act in banking law: a concept that encompasses all manner of reform, with little regard for the actual content of the original source law.

More broadly, as the foregoing historical analysis has shown, the embrace of rigidity in service of greater fairness runs the risk of making the business bankruptcy unusable. That is, because fairness is often promoted by more rules, more oversight, and more process, the reorganization system loses its ability to be useful. Extreme fairness is thus apt to be an unstable solution, as the flaws in such a system are apt to inspire swift revision.

The obvious solution is balance. What form might that take?

The current full-bodied flexibility is useful but could be better restrained by some healthy judicial skepticism. Not every trade creditor is critical, ${ }^{236}$ not every sale must be approved on the same swift timeline as General Motors, and not every priority skipping deal is inherently better than dismissal or chapter 7 liquidation. Somewhat ironically, judicial discretion needs to be harnessed to preserve the flexibility of the present system.

Mechanisms to facilitate voice are also useful, so long as they do not

and about $1 / 3^{\text {rd }}$ of creditors measured by amount could be bound to a plan that does not comply with the so-called absolute priority rule.

234. Czyzewski v. Jevic Holding Corp., 137 S. Ct. 973, 984, 197 L. Ed. 2d 398 (2017).

235. Sarah Pei Woo, Regulatory Bankruptcy: How Bank Regulation Causes Fire Sales, 99 Geo. L.J. 1615, 1622 (2011).

236. Keeping in mind that the caselaw undergirding such payments was never as stable as sometimes assumed in modern contexts. Adrian H. Joline, Railway Reorganizations, 4 BRIEF 1, 15 (1902). ("No counsel may, with any confidence, advise a client whether or not his demand comes within the class which the court will recognize as entitled to priority."). 
become so broad as to foist excessive costs on reorganizations. Nearly every modern debtor asserts that equity is "out of the money," and thus opposes the appointment of an equity committee. Given the proliferation of easy lending in recent years, it is quite likely that most cases are indeed insolvent. But some are not, or at least there might be a real question, and bankruptcy courts should not be too hasty to deny equity committees a role. ${ }^{237}$

Likewise, several recent cases - Sears and Toys "R" Us, for example have involved sizable numbers of non-unionized employees. These people have essentially no say in reorganization as presently practiced, while the shape of the reorganization will have an outsized effect on their lives. Providing a voice in suitable proceedings - namely, those where the number of employees justifies the cost - would help ensure greater fairness in modern chapter $11 .^{238}$

\section{CONCLUSION}

Through a comprehensive review of history, this paper has shown that American corporate reorganization, like other important societal trends, typically evolves in big, multi-year cycles. Extreme flexibility is met with a sharp move back toward fairness, only to move once again to flexibility. The turning points are recognizable, even if they are surprisingly rare and far apart.

We seem to be at the start of one such turning point: after almost two decades of increasing flexibility in chapter 11 practice, hints of a budding backlash abound, and the appellate courts have shown some sympathy with these critics.

But another extreme move toward fairness, like that we experienced in the New Deal, would be both misguided and unlikely to last. Instead, I have suggested the outlines of a more restrained approach, retaining the current flexibility with more skepticism about whether flexibility is always required. Moreover, if we crack the door open to further voices in the chapter 11 process, we can be more certain that any flexibility that is deployed is actually warranted.

237. Cf. Jared A. Ellias, What Drives Bankruptcy Forum Shopping? Evidence from Market Data, 47 J. Legal STUD. 119, 147 (2018) (comparing the success of junior constituencies between Delaware and other jurisdictions).

238. Such voice can be justified by the cost the bankruptcy process imposes on employees over the long term. See generally John R. Graham et al., Employee Costs of Corporate Bankruptcy (Nat'l Bureau of Econ. Research, Working Paper No. 25922, 2019), available at http://www.nber.org/papers/w25922 [https://perma.cc/824S-RXV6] (finding that an "employee's annual earnings fall by $10 \%$ the year her firm files for bankruptcy and fall by a cumulative present value of $67 \%$ over seven years."). 